\title{
Urban Heat Island and Overheating Characteristics in Sydney, Australia. An Analysis of Multiyear Measurements
}

\author{
Mat Santamouris ${ }^{1, *}$, Shamila Haddad ${ }^{1}$, Francesco Fiorito ${ }^{1}$, Paul Osmond ${ }^{1}$, Lan Ding ${ }^{1}$, \\ Deo Prasad ${ }^{1}$, Xiaoqiang Zhai ${ }^{2}$ and Ruzhu Wang ${ }^{2}$ \\ 1 Annita Lawrence Chair of High Performance Architecture, Faculty of Built Environment, \\ University of New South Wales, Sydney 2052, Australia; s.haddad@unsw.edu.au (S.H.); \\ f.fiorito@unsw.edu.au (F.F.); p.osmond@unsw.edu.au (P.O.); \\ lan.ding@unsw.edu.au (L.D.); d.prasad@unsw.edu.au (D.P.) \\ 2 Institute of Refrigeration and Cryogenics, Shanghai Jiao Tong University, Shanghai 200240, China; \\ xqzhai@sjtu.edu.cn (X.Z.); rzwang@sjtu.edu.cn (R.W.) \\ * Correspondence: m.santamouris@unsw.edu.au; Tel.: +61-293-850-729
}

Academic Editors: Constantinos Cartalis and Marc A. Rosen

Received: 4 February 2017; Accepted: 25 April 2017; Published: 29 April 2017

\begin{abstract}
It has become increasingly important to study the urban heat island phenomenon due to the adverse effects on summertime cooling energy demand, air and water quality and most importantly, heat-related illness and mortality. The present article analyses the magnitude and the characteristics of the urban heat island in Sydney, Australia. Climatic data from six meteorological stations distributed around the greater Sydney region and covering a period of 10 years are used. It is found that both strong urban heat island (UHI) and oasis phenomena are developed. The average maximum magnitude of the phenomena may exceed $6 \mathrm{~K}$. The intensity and the characteristics of the phenomena are strongly influenced by the synoptic weather conditions and in particular the development of the sea breeze and the westerly winds from the desert area. The magnitude of the urban heat island varies between 0 and $11^{\circ} \mathrm{C}$, as a function of the prevailing weather conditions. The urban heat island mainly develops during the warm summer season while the oasis phenomenon is stronger during the winter and intermediate seasons. Using data from an extended network of stations the distribution of Cooling Degree Days in the greater Sydney area is calculated. It is found that because of the intense development of the UHI, Cooling Degree Days in Western Sydney are about three times higher than in the Eastern coastal zone. The present study will help us to better design and implement urban mitigation strategies to counterbalance the impact of the urban heat island in the city.
\end{abstract}

Keywords: urban heat island; coastal cities; Sydney; Australia

\section{Introduction}

The Urban Heat Island (UHI) is the most documented phenomenon of climate change. According to recent studies, the presence of UHI is recognized in more than 400 cities around the world [1,2], The UHI refers to a higher ambient temperatures in dense urban zones compared to the surrounding suburban or rural areas. The development of the UHI is influenced by the synoptic weather conditions in the area, the local morphological and structural parameters of the city, the thermal quality of the materials used, the magnitude of the anthropogenic heat released, and the presence of heat sources and sinks in the cities [3]. The urban heat island considerably increases the peak electricity demand and the cooling energy consumption of buildings, deteriorates the levels of outdoor and indoor comfort, 
raises the concentration of several harmful pollutants, seriously affects human health and increases the risk levels for vulnerable populations [4].

Recent research has shown that because of the urban heat island, the peak electricity demand increases between $0.45 \%$ and $4.6 \%$ per degree of temperature rise [5]. In parallel, it is reported that the average cooling energy penalty induced by the urban heat island is close to $68 \mathrm{kWh} / \mathrm{p} / \mathrm{K}$, or $0.8 \mathrm{kWh} / \mathrm{m}^{2} / \mathrm{K}[6]$. Studies carried out in different cities have also shown that UHI may increase the cooling demand of buildings up to $100 \%[7,8]$. The very important increase of the cooling demand induced by the urban heat island in combination with other drivers, like population increase and the rapid penetration of air conditioning devices, may increase the global cooling needs of the residential and commercial sectors up to $750 \%$ and $275 \%$, respectively, by 2050 [9]. Furthermore, the UHI affects meteorological conditions, e.g. impacting the atmospheric boundary layer (ABL) depth in urban areas, in particular during the nighttime [10].

Besides the important energy problem induced by UHI, the impact on the thermal comfort, health and vulnerability of urban citizens should not be underestimated. Several studies have reported a serious reduction in outdoor comfort levels because of this phenomenon [11]. In parallel, large-scale measurements of the indoor environmental conditions in low-income houses during the hot summer period have shown that indoor temperatures largely exceeded the threshold temperatures for health [12]. The effects of UHI related to human health and wellbeing have been highlighted in the literature $[13,14]$. Finally, recent research has demonstrated a strong correlation between increased urban temperatures and human mortality [15].

Coastal cities suffer from the urban heat island despite the development and positive impact of the sea breeze [16]. Several experimental and numerical investigations have shown the impact of the sea on the development of the UHI in coastal cities [17-24]. Most of the investigations agree that although the UHI despite under the presence of the sea breeze, the intensity of the phenomenon in coastal areas is reduced because of the important transfer of relatively cool air into the city [25-30]. The specific interaction of the urban heat island and the sea breeze has been studied through numerical and experimental investigations. Several numerical studies have concluded that the UHI delays the flow of the sea breeze because of the creation of a stagnation region over the city $[17,19,29]$. This results in a higher cooling impact in coastal than in inland urban zones, while the cooling potential of the sea breeze is considerably reduced with an increase in the distance from the coastal areas. Other studies have concluded that the presence of the urban heat island accelerates the flow of the sea breeze towards the city and the speed of the sea breeze increases significantly compared to the case where no city exists [21,23].

The present paper investigates the magnitude and the characteristics of the UHI in a coastal city, Sydney, Australia. Ten years of climatic data from six stations, distributed in the greater Sydney area, are used. The objective of the work was to determine in depth the magnitude and the characteristics of the problem in order to propose specific mitigation and adaptation measures to counterbalance the impact of overheating in the city. This is the first time that the characteristics and magnitude of the urban heat island have been studied and reported for Sydney. The information provided will help to inform mitigation strategies to counteract the phenomenon. Also, the study provides important information on the thermal conditions of coastal zones influenced by the advection of warm air from inland. This is a rather rare climatological case and the present article is among the first to study and report it.

\section{Sydney's Geographical Location and Population}

Sydney is located on the southeast coast of Australia at $33.8^{\circ} \mathrm{S}$ latitude, bordering the Tasman Sea to the east. Metropolitan Sydney is classified as Greater Sydney, the Capital City Statistical Division, by the Australian Bureau of Statistics (ABS). Greater Sydney is the capital of the state of New South Wales (NSW). It is the largest city in Australia, covers a land area of approximately $12,367.7 \mathrm{~km}^{2}$ and is made up of 43 local councils (This number has been reduced to 30 following council amalgamations since 
this research was conducted. Hence mention of council land areas, populations, etc. below refer to the pre-amalgamation situation). The area follows the coastline from Gosford in the north to the Royal National Park in the south. The region includes Parr State Conservation Area and the Blue Mountains to the west. The Sydney metropolitan area lies within the flat Cumberland Basin to the south and west of Port Jackson, and is surrounded by the Hornsby and Blue Mountains Plateaus and steep escarpments to the north and west, with elevations of up to 300 and $600 \mathrm{~m}$ above sea level, respectively. According to the Australian Statistical Geography Standard [31], the Sydney urban area extends $70 \mathrm{~km}$ from the coastline in the east to the Blue Mountains in the west. Greater Sydney is the most populous city in Australia, with a population of approximately 4.92 million people in June 2015 [32]. Based on the land area, the current population density of metropolitan Sydney is 397.8 persons per square kilometre.

\section{Climate of Sydney}

Sydney has a humid subtropical climate [33] and is characterised by warm summers and cool winters. It features a Cfa climate based on the Köppen-Geiger climate classification [34]. The annual monthly mean temperature recorded at Observatory Hill in the central business district (CBD) ranged from $13.8^{\circ} \mathrm{C}$ to $21.7^{\circ} \mathrm{C}$ based on long-term monthly average data from 1859 to 2016 [35]. The mean daily maximum and minimum temperatures on vary between $25.9^{\circ} \mathrm{C}$ in the summer (January) and $8.1^{\circ} \mathrm{C}$ in the winter (July). January is the warmest month, with an average daily air temperature of $18.7^{\circ} \mathrm{C}$ to $25.9^{\circ} \mathrm{C}$, and the highest recorded maximum temperature of $45.8^{\circ} \mathrm{C}$. Based on long-term climate data [35], the temperature exceeds $30^{\circ} \mathrm{C}$ for an average of 14.9 days a year. In contrast, winters are cool, with temperatures dropping below $10^{\circ} \mathrm{C}$ from June to August. The annual monthly mean temperature recorded at Observatory Hill in July varied from $8.1{ }^{\circ} \mathrm{C}$ to $16.4{ }^{\circ} \mathrm{C}$, with the lowest recorded minimum temperature of $2.2^{\circ} \mathrm{C}$ [35]. The annual average temperature in Western Sydney, at Prospect Reservoir, varied from $12.2^{\circ} \mathrm{C}$ to $23.2^{\circ} \mathrm{C}$ based on long-term averages over the past 51 years, with the average daily maximum and minimum temperatures of $6.1-28.4^{\circ} \mathrm{C}$. The temperature falls above $30^{\circ} \mathrm{C}$ for an average of 45.5 days a year, which is almost three times higher than that in Sydney CBD [35]. The highest and lowest temperatures on record are $45.1^{\circ} \mathrm{C}$ and $-0.8^{\circ} \mathrm{C}$, respectively. The mean daily maximum temperature in Penrith, located approximately $50 \mathrm{~km}$ west of Sydney CBD, reaches up to $30.7^{\circ} \mathrm{C}$ with a highest temperature of $46.5^{\circ} \mathrm{C}$ on record [35]. The annual average daily maximum and minimum temperatures varied from $12.4^{\circ} \mathrm{C}$ to $24.5^{\circ} \mathrm{C}$. The coldest month in Penrith is July, with an average range of $5.5^{\circ} \mathrm{C}-17.7^{\circ} \mathrm{C}$, and a lowest temperature of $-1.4^{\circ} \mathrm{C}$. Penrith has an average of 68.6 days a year with a daily maximum of more than $30^{\circ} \mathrm{C}$ and 19.3 days a year over $35^{\circ} \mathrm{C}$ [35]. Rainfall is uniform and occurs throughout the year with an annual rainfall of approximately $1000-1500 \mathrm{~mm}$ [35].

The climate of Greater Sydney is significantly affected by its coastal position and the proximity to the ocean. This is clearly suggested by the increase in the mean and maximum summer temperatures from the coastal zone near the CBD towards the inland Western suburbs by $2-5{ }^{\circ} \mathrm{C}$. This, however, depends on the wind speed and direction.

\section{Description of the Meteorological Stations and Data}

The half hourly climate data (dry bulb temperature, wind speed and wind direction, dew point temperature, humidity and atmospheric pressure) were obtained from six Bureau of Meteorology weather stations in the Sydney Metropolitan area from 2005 to 2015 (data was sourced from the Bureau of Meteorology) [36]. The selected sites cover approximately $25 \mathrm{~km}$ from the coast to the inland border. Table 1 summarises the geographical information of the selected weather stations in this study, while Figure 1 shows the position of each of the six stations.

All data have been submitted to detailed statistical control and cleaned of possible errors.

Sydney Observatory Hill $\left(151.2050^{\circ} \mathrm{E}, 33.8607^{\circ} \mathrm{S}\right)$ is the reference station in this study, which is located on the coast in the City of Sydney, almost at the heart of Sydney CBD. The City of Sydney is a mixed-use area (consisting of residential, commercial, and industrial land use), and encompasses a total land area of 2672 hectares $\left(27 \mathrm{~km}^{2}\right)$. According to the 2015 census data released by the Australian 
Bureau of Statistics, the City of Sydney has a population of 205,339, resulting in a population density of 76.84 persons per hectare [32]. The City of Sydney tree canopy cover is 15.2 percent [37].

Table 1. Geographical information for the selected weather stations.

\begin{tabular}{|c|c|c|c|c|c|}
\hline Stations & Latitude $\left({ }^{\circ} \mathrm{S}\right)$ & Longitude $\left({ }^{\circ} \mathrm{E}\right)$ & Altitude (m) & Region & Year Opened \\
\hline Sydney Observatory Hill & 33.8607 & 151.2050 & 39 & CENSW $^{1}$ (coast) & 1858 \\
\hline Sydney Airport AMO ${ }^{2}$ & 33.9465 & 151.1731 & 6 & CENSW (coast) & 1929 \\
\hline Canterbury Racecourse AWS ${ }^{3}$ & 33.9057 & 151.1134 & 3 & CENSW (inland) & 1995 \\
\hline Bankstown Airport AWS & 33.9181 & 150.9864 & 7 & CENSW (inland) & 1968 \\
\hline Sydney Olympic Park AWS (Archery Centre) & 33.8338 & 151.0718 & 4 & CENSW (inland) & 2011 \\
\hline Sydney Olympic Park (VIS Meter) & 33.8521 & 151.0646 & 28 & CENSW (inland) & 1995 \\
\hline Terrey Hills AWS & 33.6908 & 151.2253 & 199 & CENSW (inland) & 2004 \\
\hline
\end{tabular}

Note: ${ }^{1} \mathrm{CENSW}=$ Central East New South Wales; ${ }^{2} \mathrm{AMO}=$ Airport Meteorological Office; ${ }^{3}$ AWS = Automatic Weather Stations.

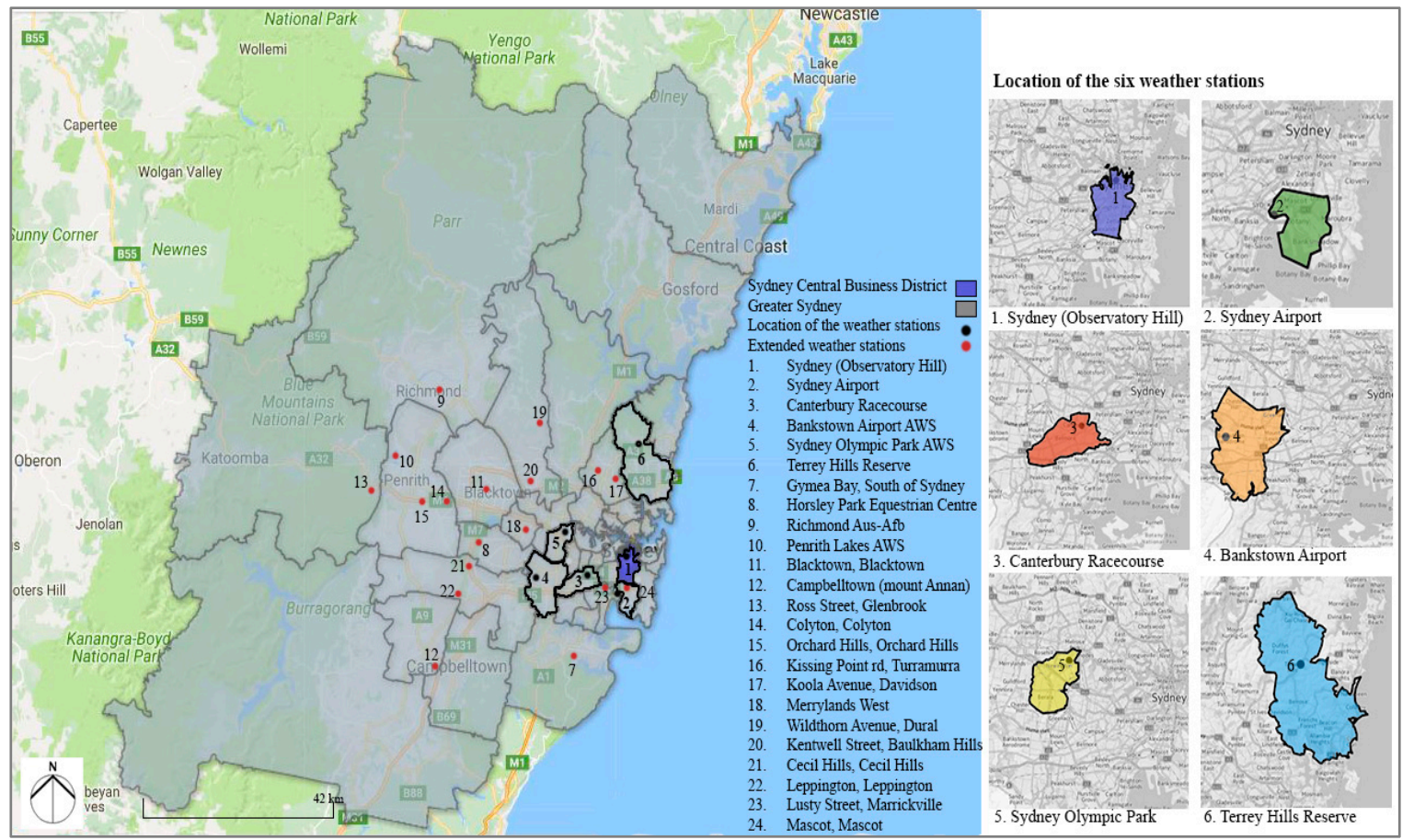

Figure 1. Position of the considered Meteorological Stations.

Sydney Airport AMO $\left(151.1731^{\circ} \mathrm{E}, 33.9465^{\circ} \mathrm{S}\right)$ is located on the coast, in the City of Botany Bay. The City of Botany Bay is located approximately $6 \mathrm{~km}$ south of the Sydney CBD, surrounded by Sydney inner suburbs on its non-coastal boundaries. The land around the Sydney Airport is a mixed-use development with aviation purposes, and residential, commercial, and industrial areas, which encompasses a total land area of 2706 hectares $\left(27 \mathrm{~km}^{2}\right)$, including significant foreshore zones. The 2015 estimated population for the City of Botany Bay is 46,587 with a population density of 17.22 persons per hectare [32]. According to [37], tree canopy cover in the City of Botany Bay is approximately 12.1 percent of the total land area.

Canterbury Racecourse AWS and Bankstown Airport AWS represent inland suburbs of Sydney. Canterbury Racecourse AWS (151.1134 $\left.{ }^{\circ} \mathrm{E}, 33.9057^{\circ} \mathrm{S}\right)$ is located in Canterbury City, southwest of Sydney, approximately $17 \mathrm{~km}$ away from the Sydney CBD and $7 \mathrm{~km}$ from the nearest coastline. Canterbury City is mainly a residential area with few industrial and commercial sites. The City has a total land area of about 3356 hectares $\left(34 \mathrm{~km}^{2}\right)$, with an estimated population of 151,746 and a population density of 45.21 persons per hectare [32]. The tree canopy cover in Canterbury City is about 17.5 percent of the total land area [37]. 
Bankstown Airport AWS $\left(150.9864^{\circ} \mathrm{E}, 33.9181^{\circ} \mathrm{S}\right)$ is located southwest of Sydney suburban areas in Bankstown City, approximately $22 \mathrm{~km}$ South-west of the Sydney CBD and $16 \mathrm{~km}$ from the nearest coastal zone. Bankstown City features residential, commercial and industrial land uses in the total land area of 7682 hectares $\left(77 \mathrm{~km}^{2}\right)$ with a population of 203,202 and a population density of 26.45 persons per hectare [32]. The tree canopy cover in Bankstown City is approximately 17.1 percent [37].

Sydney Olympic Park AWS (Archery Centre and VIS Meter (Observations of climate data have been drawn from Sydney Olympic Park AWS (Archery Centre) since 2011, which is $2 \mathrm{~km}$ north of the previous weather station at Sydney Olympic Park.)) and Terry Hills AWS are representative of Sydney inland suburbs. Sydney Olympic Park $\left(151.0718^{\circ} \mathrm{E}, 33.8338^{\circ} \mathrm{S}\right.$ and $\left.151.0646^{\circ} \mathrm{E}, 33.8521^{\circ} \mathrm{S}\right)$ is located in Auburn City, approximately $14 \mathrm{~km}$ west of the Sydney CBD in proximity to Parramatta River and $13 \mathrm{~km}$ away from the nearest coastline. Auburn City is predominately mixed-use, including residential and industrial areas with some major commercial, recreational, and parkland land uses. Auburn City encompasses a total land area of 3249 hectares $\left(32 \mathrm{~km}^{2}\right)$, with an estimated population of 88,059 and a population density of 27.11 persons per hectare [32]. Auburn City encompasses 15.4 percent tree canopy cover for the total land area [37].

Terrey Hills AWS $\left(151.2253^{\circ} \mathrm{E}, 33.6908^{\circ} \mathrm{S}\right)$ is part of the northern forest district positioned at $199 \mathrm{~m}$ above sea level. This station is located $25 \mathrm{~km}$ North of Sydney CBD in Warringah, $7.5 \mathrm{~km}$ from the nearest coastline. Warringah is mainly a residential area with some industrial and commercial sites. It covers a total land area of 14,936 hectares $\left(149 \mathrm{~km}^{2}\right)$ and includes a large area of dense greenery such as National Park, bushland, and reserves. The total tree canopy cover is 58 percent [37]. There are 156,693 people estimated living in Warringah suburban areas, with a population density of 10.49 persons per hectare [32].

For the period analysed, 2005-2015, the nighttime ambient temperature varied from $-1.1^{\circ} \mathrm{C}$ to $36.2^{\circ} \mathrm{C}$. The average, minimum and maximum nighttime temperatures for all stations were from $14.4{ }^{\circ} \mathrm{C}$ to $17.1^{\circ} \mathrm{C},-1.1{ }^{\circ} \mathrm{C}$ to $4{ }^{\circ} \mathrm{C}$, and $33.9^{\circ} \mathrm{C}$ to $36.2{ }^{\circ} \mathrm{C}$, respectively. Stations located in the western part of the city (Bankstown, Canterbury and Olympic Village) presented a lower average and minimum nighttime temperature compared to the coastal stations of Eastern Sydney. In particular the average and minimum nighttime temperatures in Western Sydney were lower by $1.3^{\circ} \mathrm{C}$ and $3.3^{\circ} \mathrm{C}$ than those recorded in the eastern part of the city. Insignificant differences concerning the absolute maximum night time temperature were observed between Western and Eastern Sydney (Figure 2).

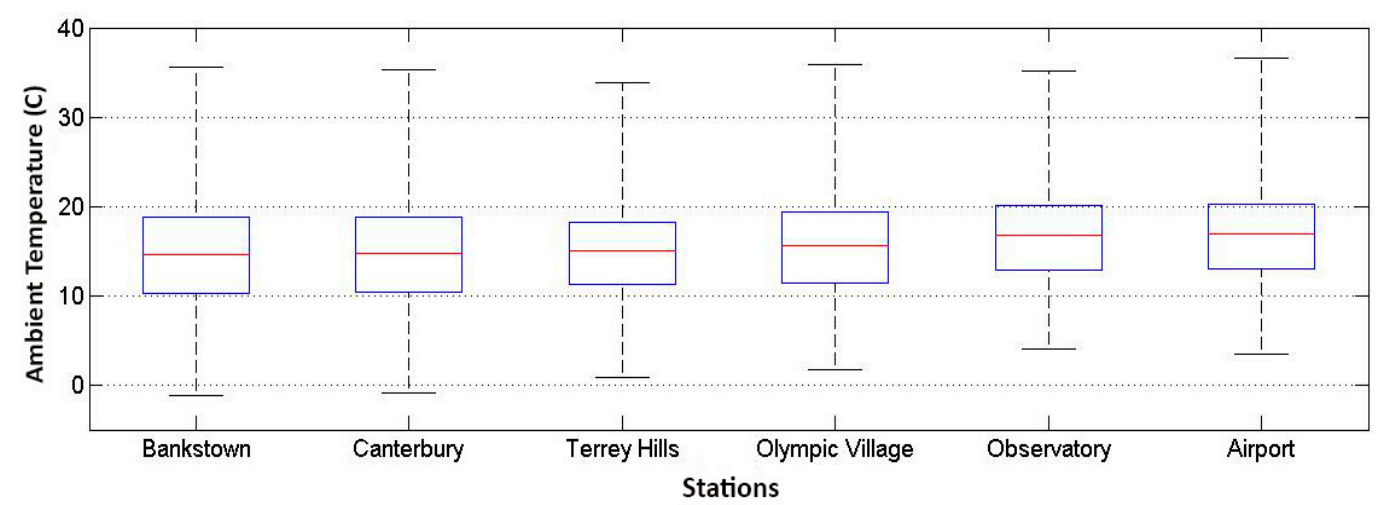

Figure 2. Variation of the nighttime ambient temperature for the six considered stations.

The day time ambient temperature during the study period varied from $1.9^{\circ} \mathrm{C}$ to $44.6{ }^{\circ} \mathrm{C}$. The multiyear average ambient temperature was $18.4^{\circ} \mathrm{C}$ in Terrey Hills, $19.2^{\circ} \mathrm{C}$ at the Observatory, 19.6 ${ }^{\circ} \mathrm{C}$ in Canterbury, $20.0^{\circ} \mathrm{C}$ in Bankstown, $20.1^{\circ} \mathrm{C}$ in the Olympic Village and $20.2{ }^{\circ} \mathrm{C}$ at the airport. Minimum ambient temperatures varied from $1.9^{\circ} \mathrm{C}$ to $4.0^{\circ} \mathrm{C}$ in the western part of the city and between $5.2^{\circ} \mathrm{C}$ and $5.4^{\circ} \mathrm{C}$ in the coastal eastern suburbs. The absolute maximum temperature ranged between $43.8^{\circ} \mathrm{C}$ and $44.6{ }^{\circ} \mathrm{C}$, while insignificant differences were observed between the various stations. The lowest minimum, average and maximum temperatures were observed at the Terrey Hills station, located in a green zone of Northern Sydney (Figure 3). 


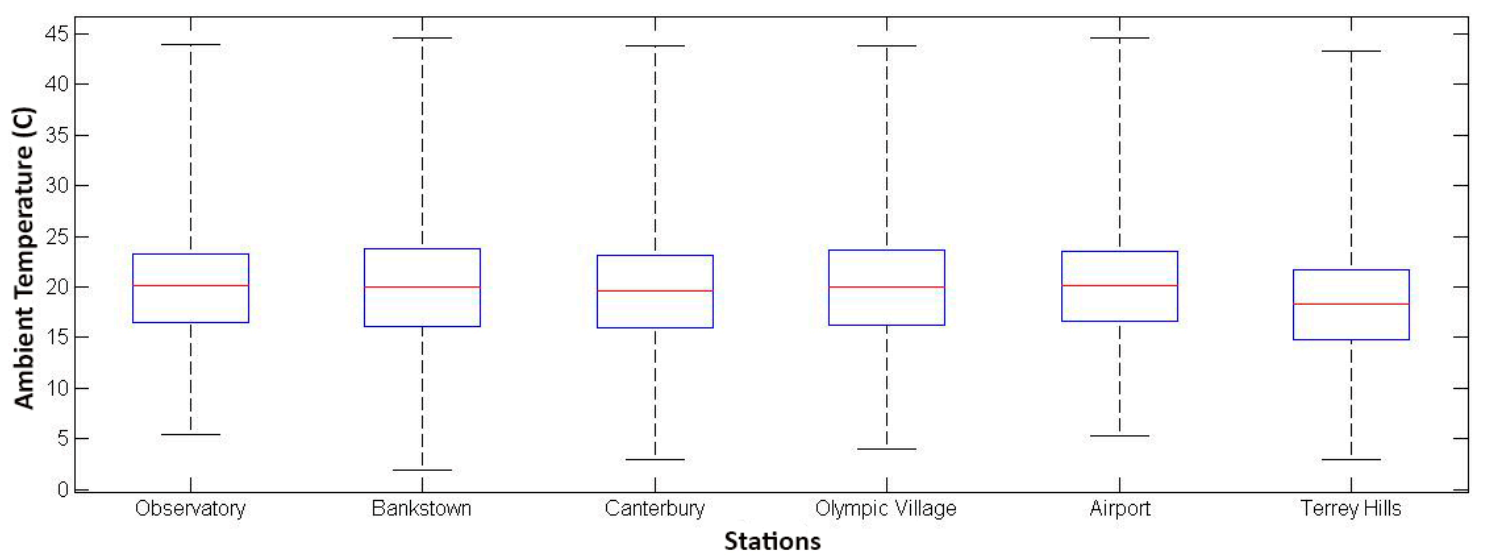

Figure 3. Variation of the daytime ambient temperature for the six considered stations.

\section{Nighttime Urban Heat Island Intensity and Characteristics}

The magnitude and variability of the night time urban heat island has been calculated for the five considered stations for the period between 2005 and 2015. The magnitude of the Urban Heat Island is calculated on "half-hourly" basis. The Observatory station is used as the reference urban station, given that it is located in the center of the city. The UHI intensity in a location is calculated as the instant difference of the temperature in the area minus the corresponding temperature at the Observatory. The calculated range of values is given in Figure 4. Given that the nighttime ambient temperature in Western Sydney is considerably lower than in the coastal eastern part, the average magnitude of the night $\mathrm{UHI}$ is negative at all stations except the airport. The range of the average night UHI varies between $0.12 \mathrm{~K}$ in the airport, $-1.13 \mathrm{~K}$ in the Olympic Village, $-1.67 \mathrm{~K}$ in the Terrey Hills, $-1.95 \mathrm{~K}$ in Canterbury and $-2.1 \mathrm{~K}$ in the Bankstown station. The corresponding maximum values vary between $5.0 \mathrm{~K}$ to $6.7 \mathrm{~K}$, while the minimum night $\mathrm{UHI}$ intensity is between $-9.3 \mathrm{~K}$ and $-10.7 \mathrm{~K}$ for the three Western stations, (Bankstown, Canterbury and Olympic Village), and between $-6.5 \mathrm{~K}$ and $-7.0 \mathrm{~K}$ for the airport and Terrey Hills. The maximum amplitude of the night oasis phenomenon is present in most of the stations during the early morning hours ( 6 a.m.) or, in some rare cases, at 11 p.m.

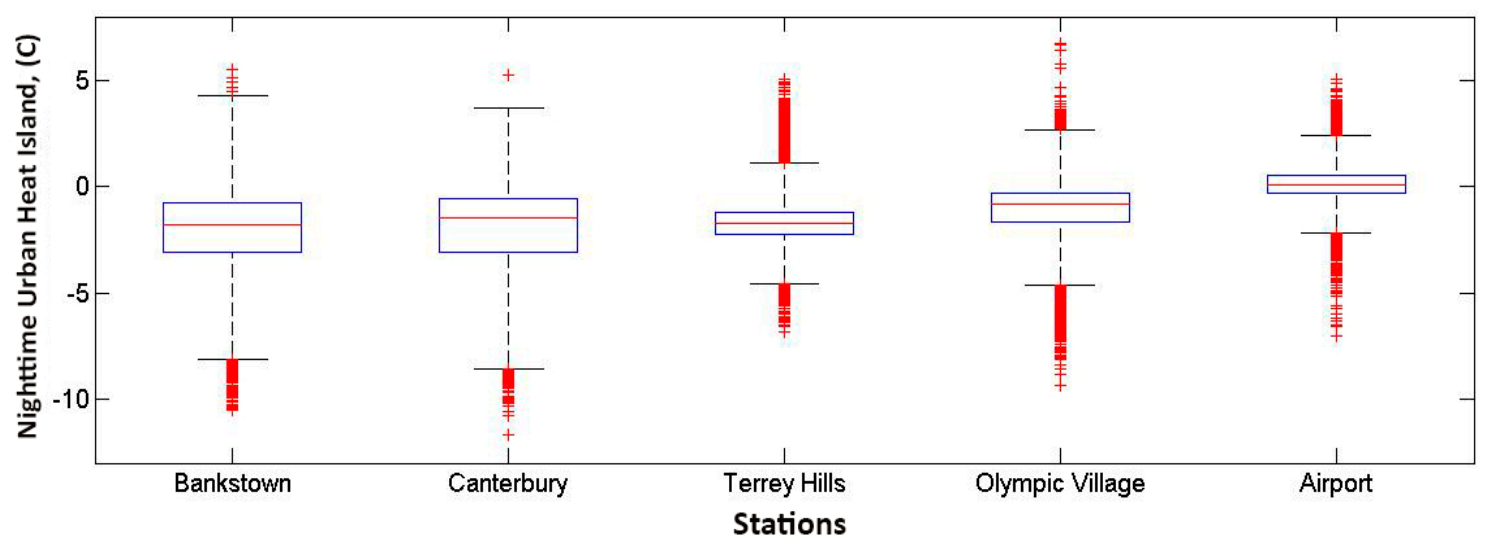

Figure 4. Variability of the nighttime UHI at the five selected stations.

The cumulative frequency distribution of the nighttime UHI for the five stations is given in Figure 5. Cumulative frequency graphs help to understand the distribution of the magnitude of the urban heat island intensity during the considered period. As shown, in the western stations and Terrey Hills, the night UHI is negative for almost $90-95 \%$ of the studied period, while in the airport the UHI intensity is negative for about $50 \%$ of the time. With the exception of the Terrey Hills station, located in the proximity of a large urban greenery reserve, the frequency of negative values, as well as the 
absolute amplitude of the night UHI, increases with distance from the coastline. This is because night time radiative and convective cooling processes are more significant in the western than in the eastern zones of the city, because of the decreased density, the reduced accumulated solar heat during the daytime, and the proximity to agricultural zones.

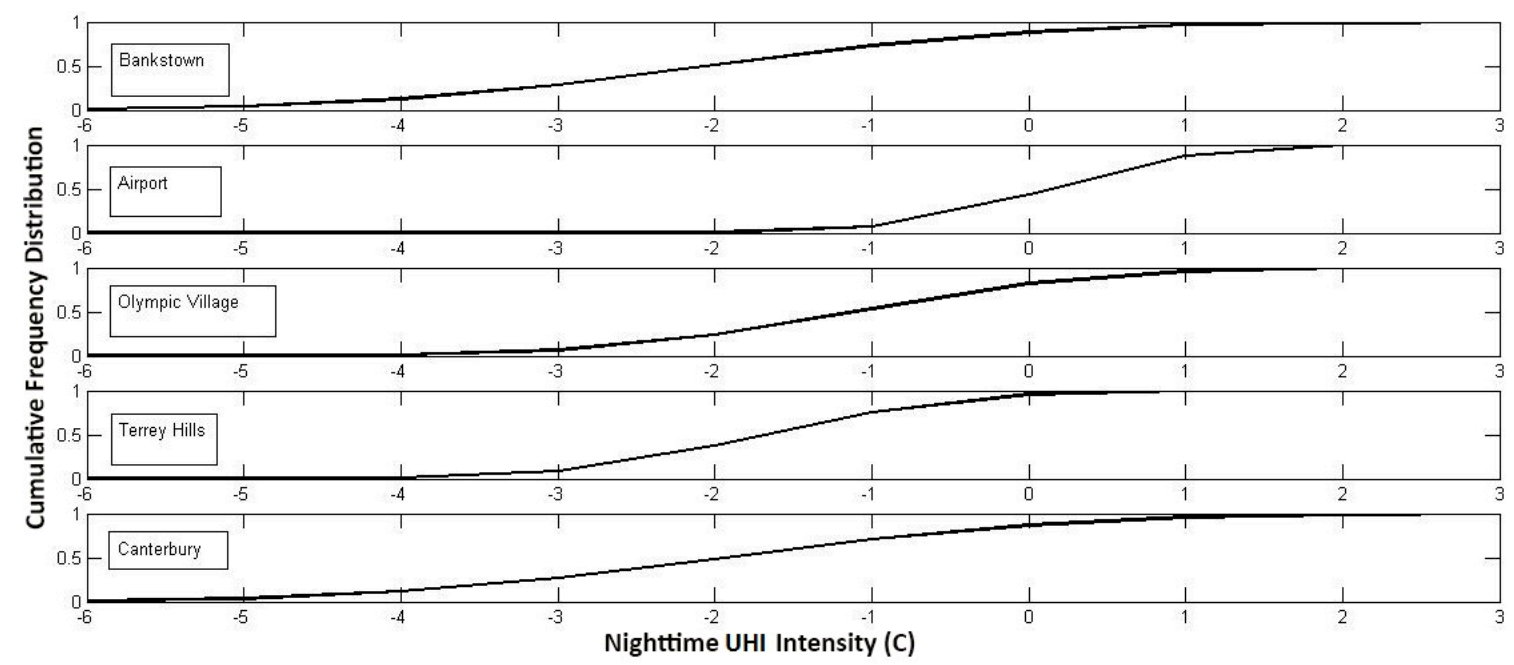

Figure 5. Cumulative frequency distribution of the nighttime UHI intensity for the five stations.

A significant correlation is observed for the three Western Sydney stations (Bankstown, Canterbury and Olympic Village), between the levels of the ambient temperature recorded in the reference station and the nighttime magnitude of the UHI (Figure 6). It is observed that the magnitude of the oasis effect in Western Sydney is decreasing and even minimized during the warm summer period. A possible explanation is that in the western part of the city, an important heating mechanism is established during the warm period, because of the advection of warm air from the inland, while at the same time, the Eastern Suburbs benefit from the significant cooling mechanism of the sea breeze. A similar phenomenon is described in [7]. In parallel, the absolute magnitude of the night oasis effect in Terrey Hills is intensified during the warm summer period, because of the important evapotranspiration cooling mechanism in the area.
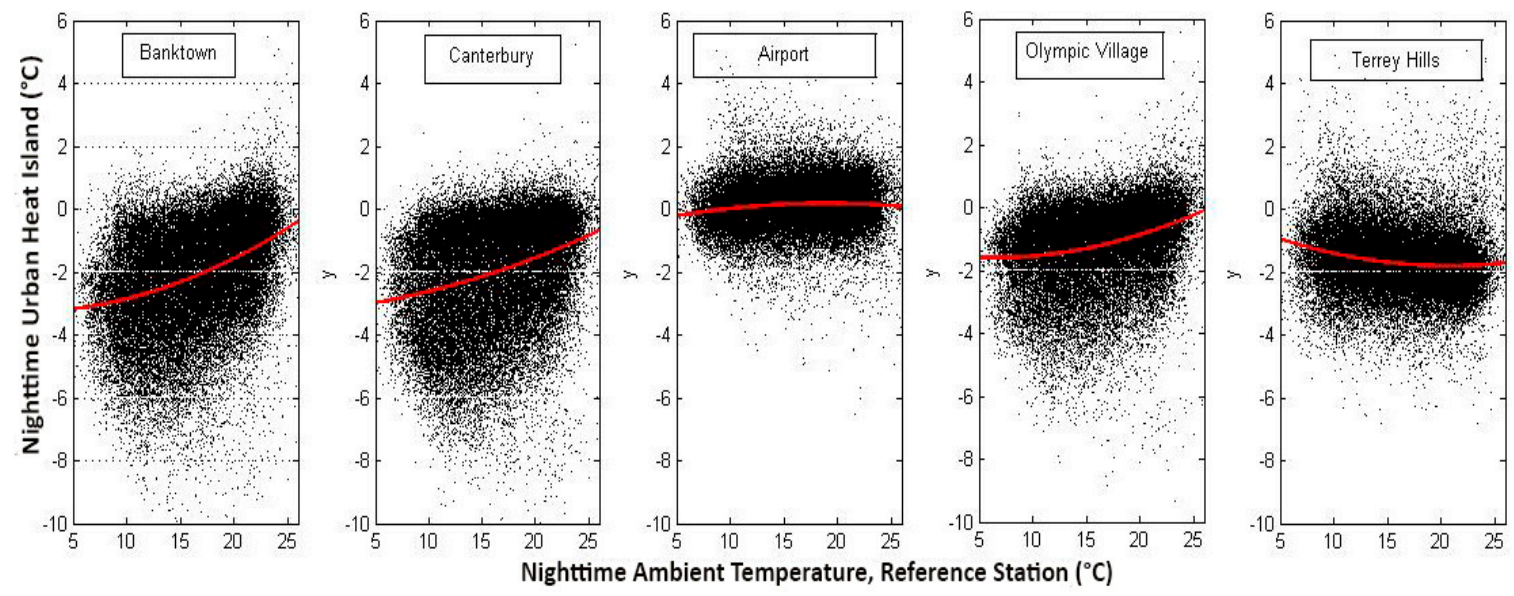

Figure 6. Correlation between the levels of the ambient temperature recorded in the reference station and the nighttime magnitude of the UHI for Canterbury Station (the red lines represent moving averages).

It is well known that the UHI is better developed under low wind conditions [38]. Several UHI studies in European, Asian and Australian cities have demonstrated that UHI is better developed 
below a threshold wind speed that depends on the city's characteristics [39-42]. Strong winds may modify the cooling and heating rates in both the urban and rural environments and decrease the intensity of the UHI phenomenon. A quite strong correlation is found between the wind speed and the magnitude of the UHI in the three West Sydney stations (Figure 7). For low wind speeds, the magnitude of the nocturnal oasis effect developed in Western Sydney is significant. This phenomenon is gradually reduced as wind speed increases, and is almost minimized for wind speeds higher than $8 \mathrm{~m} / \mathrm{s}$. Higher wind speeds are associated with important advection of air masses that tend to minimize any temperature differences. In the airport station, the average magnitude of the UHI is not found to be affected by the wind speed; however, its fluctuation is seriously reduced close to zero, as convective phenomena of similar magnitude become dominant both in the reference and the airport stations.
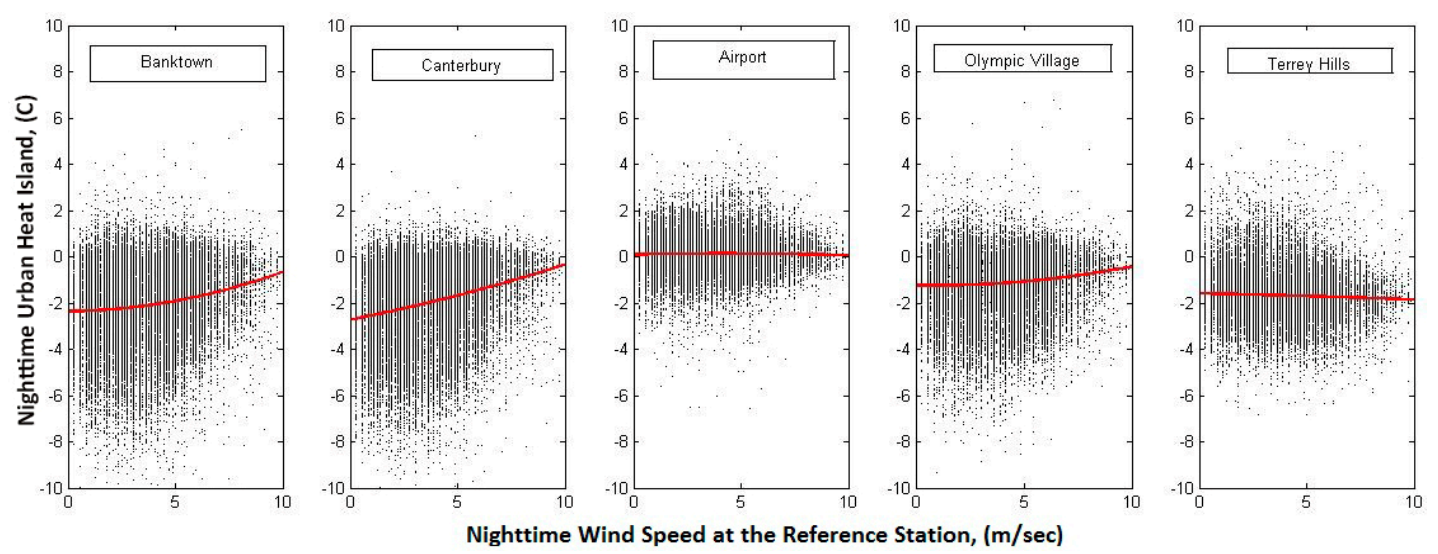

Figure 7. Correlation between the wind speed and the magnitude of the UHI in the three West Sydney stations (the red lines represent moving averages).

To better demonstrate the relation between the magnitude of the nocturnal oasis effect, the wind speed and the ambient temperature levels, the available data for the station in Canterbury have been classified in 11 wind speed clusters from 0 to $11 \mathrm{~m} / \mathrm{s}$. The average wind speed, ambient temperature and nocturnal UHI intensity were calculated for each cluster. Their correlation is plotted in Figure 8 . As shown, the magnitude of the nocturnal oasis phenomenon decreases considerably under strong wind conditions, while low wind speeds correspond to high magnitudes of the nocturnal oasis effect and higher average ambient temperatures. Under similar average temperature conditions, the intensity of the wind speed determines almost completely the magnitude of the nocturnal oasis effect, and low wind speeds help to develop a stronger oasis phenomenon.

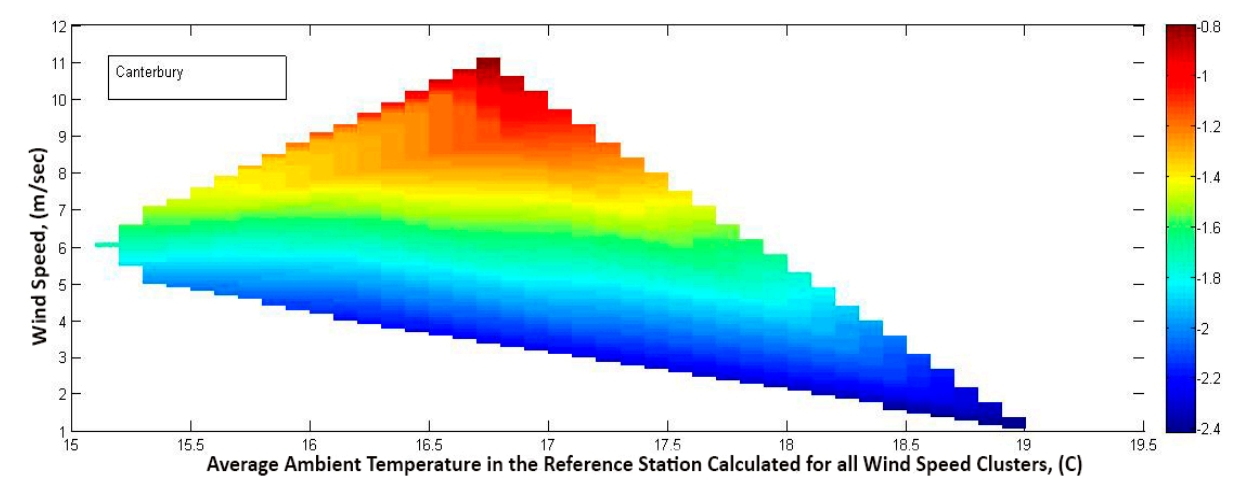

Figure 8. Correlation between the average wind speed, ambient temperature, and nocturnal UHI intensity as calculated for each cluster. 


\section{Daytime Urban Heat Island Intensity and Characteristics}

The day time ( 8 a.m. -8 p.m.) intensity of the urban heat island is calculated for the whole 10 year period. The magnitudes of the UHI at all stations are given in Figure 9. The spatial distribution of temperature differences across the city is characterized by an important variability, which results either in the development of a strong positive or negative urban heat island. The $99 \%$ percentile of the maximum UHI intensity in the three stations of Western Sydney varies between $3.8 \mathrm{~K}$ in Canterbury, $5.1 \mathrm{~K}$ in the Olympic Village, and $5.7 \mathrm{~K}$ in Bankstown. In parallel, the corresponding values at the Airport and in Terrey Hills are close to $3.2 \mathrm{~K}$ and $2.7 \mathrm{~K}$ respectively. The $99 \%$ percentile of the intensity of the developed oasis phenomenon varies between $-2.7 \mathrm{~K}$ and $-5.1 \mathrm{~K}$ in all stations. The absolute maximum UHI intensity in Western Sydney may reach 7-10 K while the absolute maximum intensity of the developed oasis phenomenon is of the same order of magnitude.

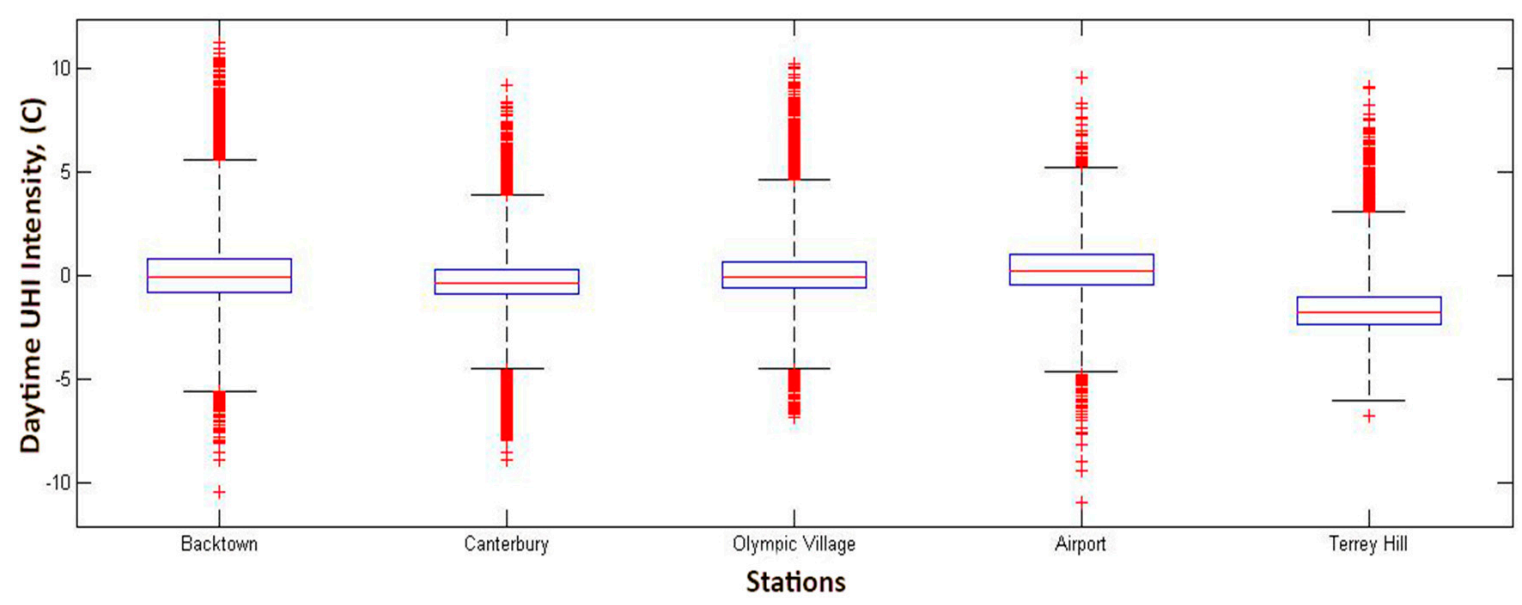

Figure 9. Levels of daytime UHI magnitude at all stations.

Figure 10 presents the day time cumulative frequency distribution of the UHI at the five stations. As shown, $\mathrm{UHI}$ is positive for $61 \%, 54 \%, 52 \%, 40 \%$ and $11 \%$ of the time in the stations of the Airport, Olympic Village, Bankstown, Canterbury and Terrey Hills, respectively.

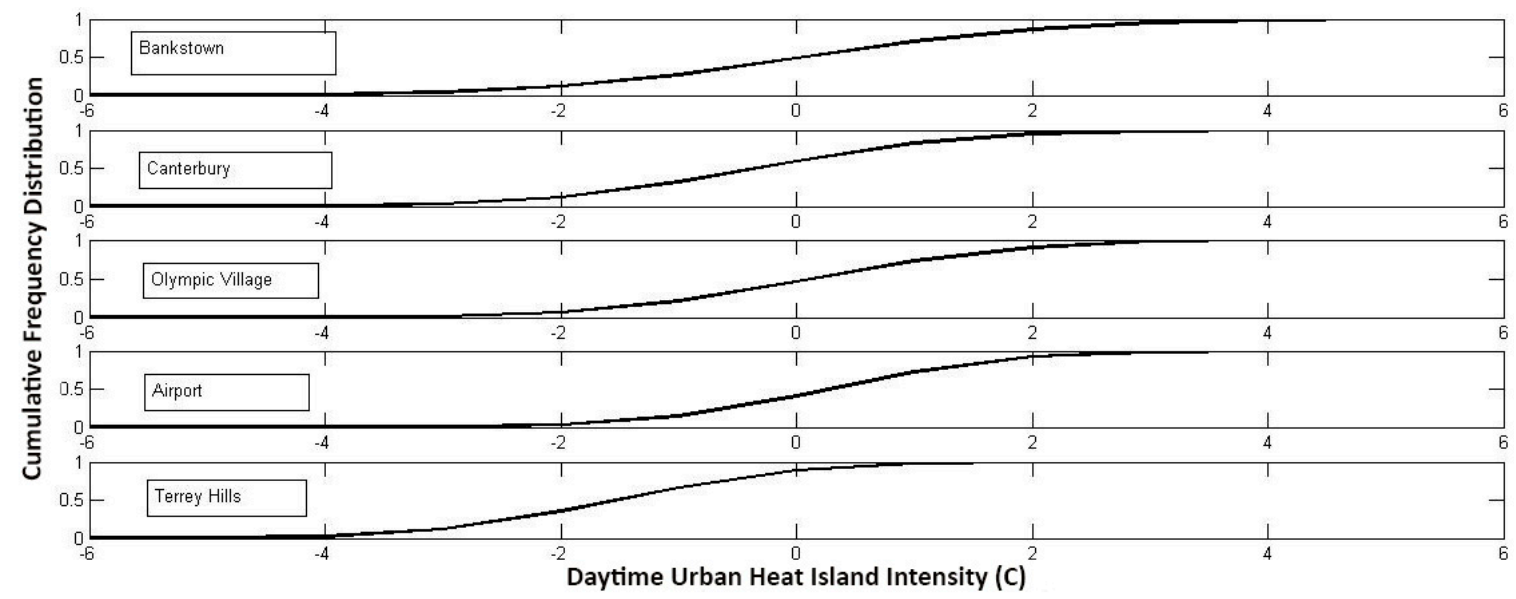

Figure 10. Daytime cumulative frequency distribution of the UHI in the five stations. 
Given the variability of the UHI intensity observed mainly in the western part of the city, a detailed analysis aimed at investigating the reasons for the UHI characteristics has been performed for the Bankstown station. The station presents the highest and lowest UHI intensities during the studied period and is characterized by a significant annual variability. It is also the most characteristic among all stations located in Western Sydney.

Using fuzzy clustering techniques, all data are classified into five clusters according to the magnitude of the UHI intensity. The first cluster corresponds to high positive UHI values and is centred on UHI intensity equal to $4.9 \mathrm{~K}$. This cluster includes almost $3.8 \%$ of the whole data. The second cluster, corresponds to moderate positive UHI intensities, is centred on UHI intensity equal to $1.84 \mathrm{~K}$, and includes $39 \%$ of the data. The third cluster corresponds to small positive or negative UHI intensities, is centred at $0.23 \mathrm{~K}$ and includes $33.4 \%$ of the data, while the fourth cluster includes small negative UHI intensities, is centred at $-0.93 \mathrm{~K}$ and involves $16.5 \%$ of the data. Finally, the last cluster is centred at $-3.35 \mathrm{~K}$, includes medium and high negative UHI intensities and contains $7.3 \%$ of the data.

First Cluster: High Positive UHI Intensity. The first cluster includes data for the periods when the UHI intensity varied between $11.25 \mathrm{~K}$ and $3.6 \mathrm{~K}$. The corresponding levels of the ambient temperature, wind speed and wind direction in the reference and the Bankstown stations are given in Figure 11. The ambient temperature in the reference station varied between $13.2^{\circ} \mathrm{C}$ and $35.5^{\circ} \mathrm{C}$, with an average close to $25.7^{\circ} \mathrm{C}$, while in the Bankstown station it varied between $16.9^{\circ} \mathrm{C}$ and $41.8^{\circ} \mathrm{C}$ with an average around $30.8^{\circ} \mathrm{C}$. The wind speed at both stations was quite similar and varied between $0.3 \mathrm{~m} / \mathrm{s}$ and $12 \mathrm{~m} / \mathrm{s}$, with an average close to $5 \mathrm{~m} / \mathrm{s}$.

However, a very important difference was observed concerning the wind direction in both stations. The reference station was mainly exposed to low-temperature easterly winds coming from the ocean direction, while in the Bankstown station, a significant part of the wind was from the western direction (Figure 12). Westerly winds in summer are of quite high temperature and come from the inland desert area. All the observed cases with very high UHI intensities corresponded to westerly winds in the Bankstown station. When the prevailing winds in the Bankstown station were from the east, and with a very high degree of probability they corresponded to a weak penetration of the sea breeze, the $\mathrm{UHI}$ intensity was at the lower limits of this cluster. The combination of easterly and southeasterly low-temperature winds in the reference station together with the westerly high temperature winds in the Blacktown station is the main reason for the very high UHI intensities observed.
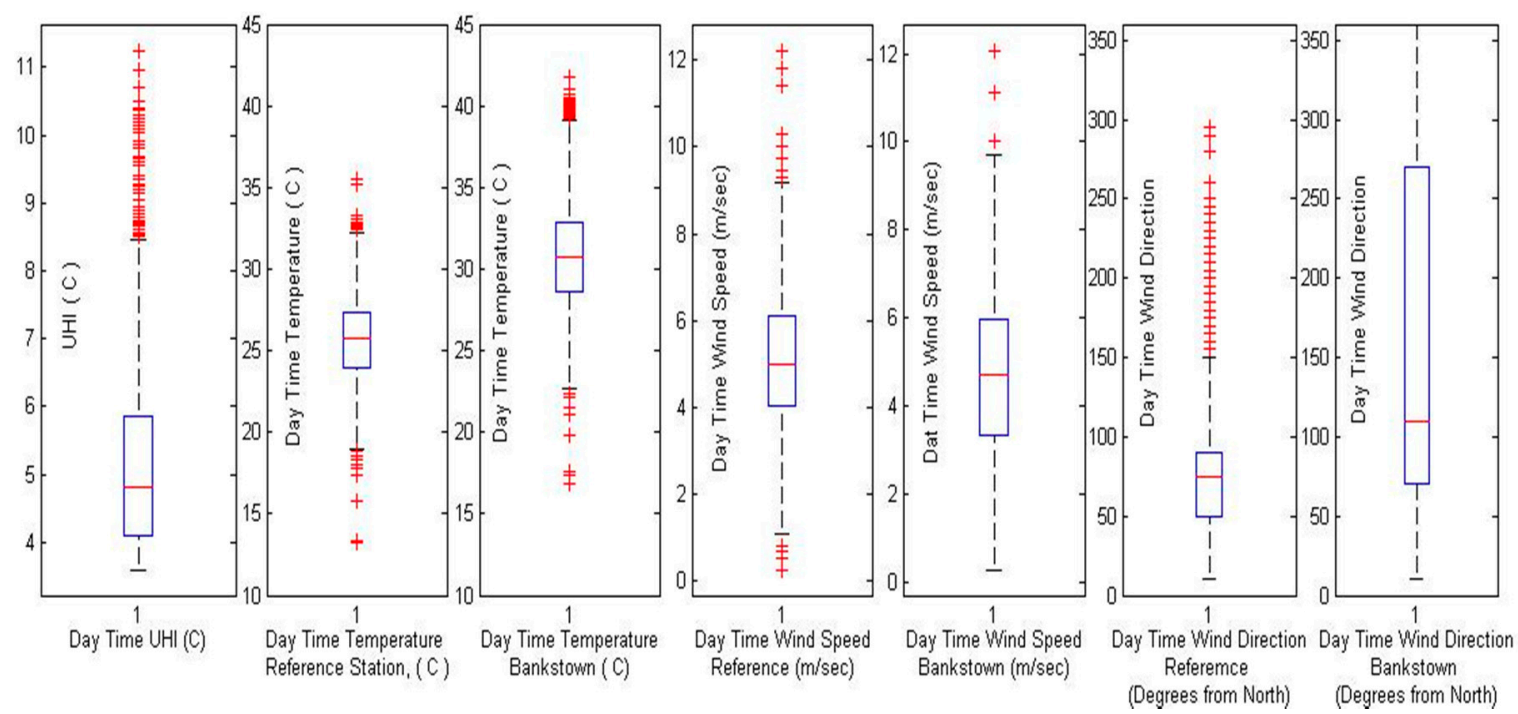

Figure 11. Levels of the daytime ambient temperature, wind speed and wind direction in the reference and the Bankstown stations in the first cluster. 

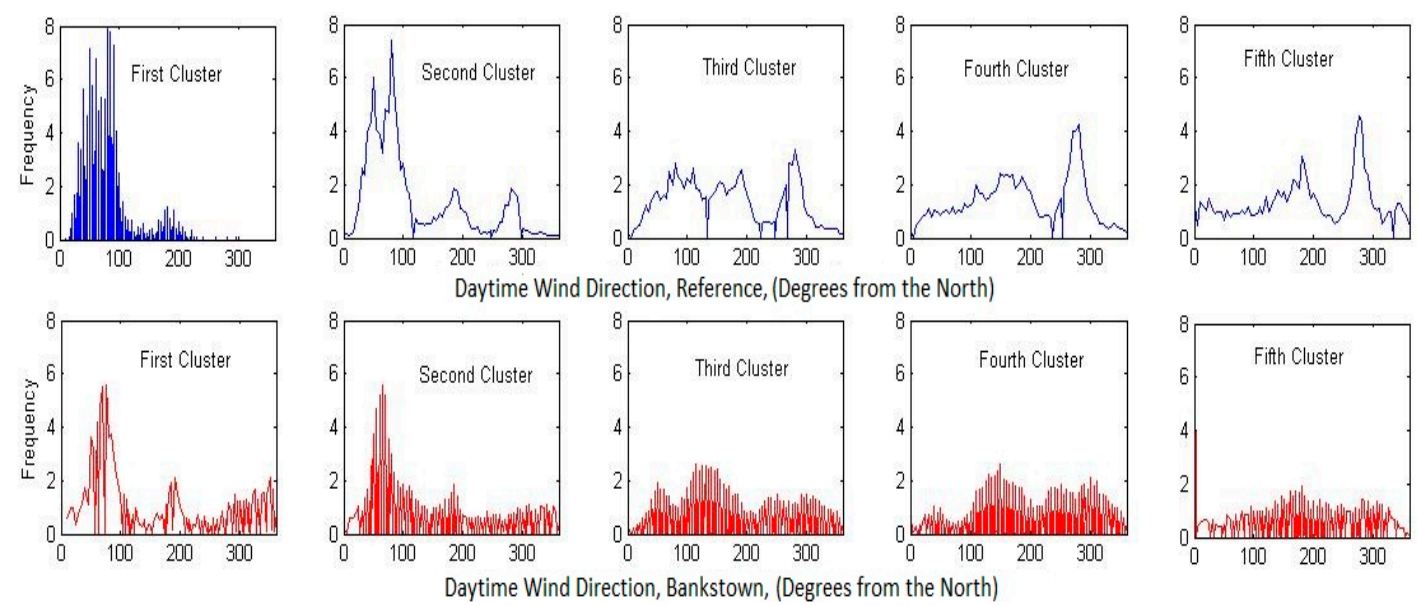

Figure 12. Frequency of the daytime wind direction in the reference and the Bankstown station for the five clusters.

Second Cluster: Moderate Positive UHI intensity. The second cluster includes climatic data where the UHI intensity was between $1.0 \mathrm{~K}$ and $3.6 \mathrm{~K}$. The corresponding ambient temperature, wind speed and wind direction conditions in both the reference and the Bankstown stations are given in Figure 13. The ambient temperature in the reference station ranged from $3.4^{\circ} \mathrm{C}$ to $41.6^{\circ} \mathrm{C}$, with an average close to $22{ }^{\circ} \mathrm{C}$. Ambient temperature in the Bankstown station varied between $8.6^{\circ} \mathrm{C}$ and $44.5^{\circ} \mathrm{C}$ with an average close to $23.9^{\circ} \mathrm{C}$. As observed, the levels of ambient temperature in this second cluster are on average substantially lower than those in the first cluster. Similar to the night period, very high UHI intensities correspond to higher ambient temperatures. The wind speed in both stations was quite similar and varied between 0 and $14 \mathrm{~m} / \mathrm{s}$, with an average close to $5 \mathrm{~m} / \mathrm{s}$. Wind speed conditions in this second cluster are similar to the ones observed in the first cluster. Wind in the reference station was from eastern, NE and SE directions, while in some cases winds from the west were observed. As already mentioned, winds of NE, SE, and Eastern orientations are from the ocean side and are of relatively low temperature. At the Bankstown station, high frequencies of easterly winds were observed, probably corresponding to a weak penetration of the sea breeze. Under these conditions the $\mathrm{UHI}$ intensity was close to the lower limits of the present cluster. On the contrary, when the wind was flowing from western orientations, the UHI intensity was close to the upper limit of the present cluster, in a similar way as in the first cluster.

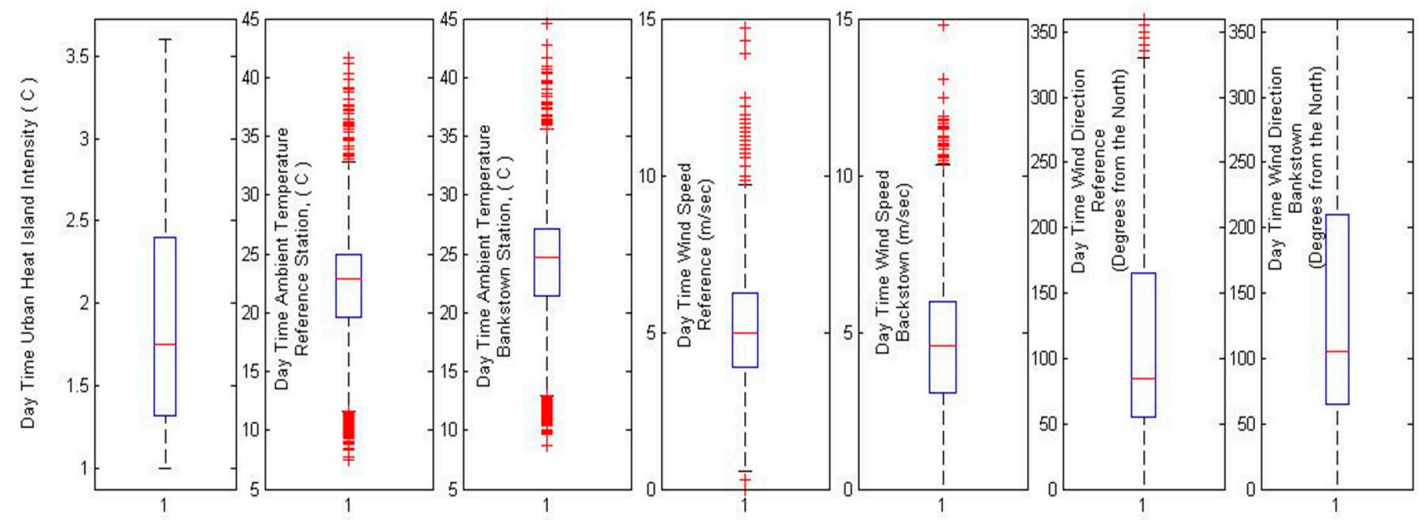

Figure 13. Levels of the daytime ambient temperature, wind speed and wind direction in the reference and the Bankstown stations in the second cluster.

Third Cluster: Negligible UHI intensity. The third cluster includes climatic data corresponding to low $\mathrm{UHI}$ intensities ranging between $-0.3 \mathrm{~K}$ and $1.0 \mathrm{~K}$. The corresponding ambient temperature, wind 
speed and wind direction data for the reference and the Bankstown stations are given in Figure 14. The ambient temperature in the reference station varied between $6.3^{\circ} \mathrm{C}$ and $43.7^{\circ} \mathrm{C}$ with an average close to $19.9^{\circ} \mathrm{C}$, while the temperature in the Bankstown station ranged between $6.2^{\circ} \mathrm{C}$ and $44.1{ }^{\circ} \mathrm{C}$, with an average around $20.2^{\circ} \mathrm{C}$. The wind speed was very similar in both stations ranging from $0.0 \mathrm{~m} / \mathrm{s}$ to $14 \mathrm{~m} / \mathrm{s}$, with an average close to $4.7 \mathrm{~m} / \mathrm{s}$. The wind direction did not differ significantly between the two stations and the air was mainly blowing from Southern, Eastern, and Western directions. Given that in both stations the wind speed and wind direction followed quite similar patterns, the strength of the developed UHI intensity was quite reduced and close to zero.
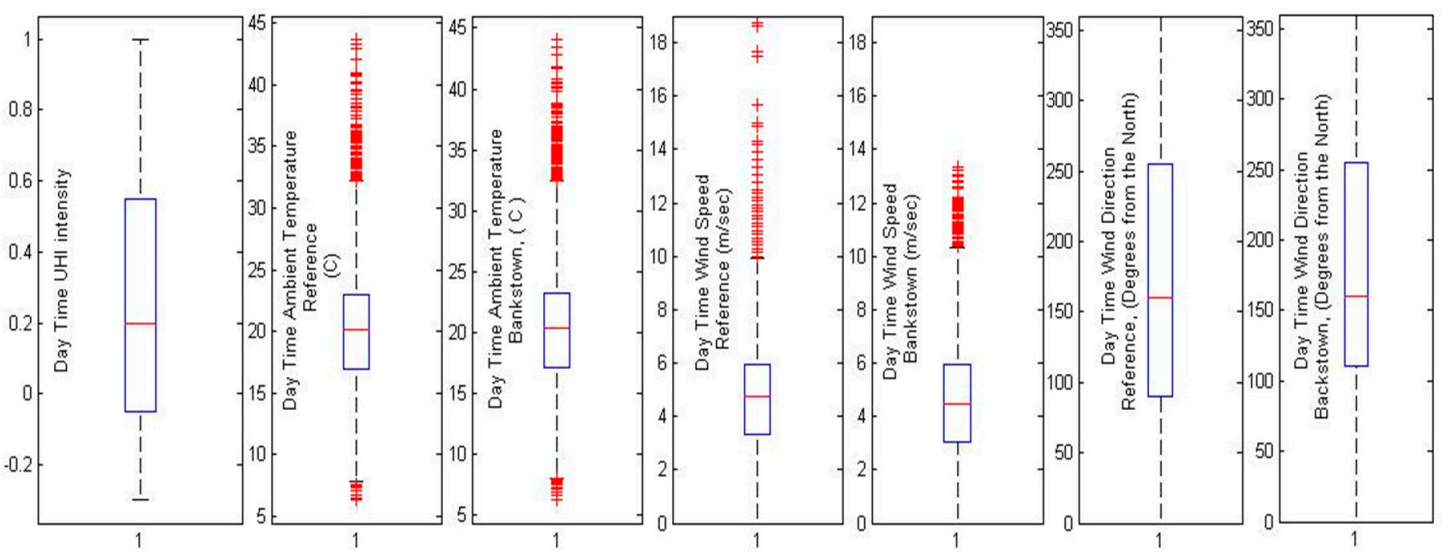

Figure 14. Levels of the daytime ambient temperature, wind speed and wind direction in the reference and the Bankstown stations in the third cluster.

Fourth Cluster: Moderate Negative UHI intensity. The fourth cluster includes climatic data for all cases corresponding to moderate negative UHI intensities ranging between $-0.3 \mathrm{~K}$ and $-2 \mathrm{~K}$. The corresponding data for the ambient temperature, wind speed and wind direction in both the stations are given in Figure 15. The ambient temperature in the reference station was between $6{ }^{\circ} \mathrm{C}$ and $45^{\circ} \mathrm{C}$ with an average close to $18.9^{\circ} \mathrm{C}$, while in the station of Bankstown the ambient temperature ranged between $4{ }^{\circ} \mathrm{C}$ and $44.6^{\circ} \mathrm{C}$, with an average around $18^{\circ} \mathrm{C}$. The wind speed levels were quite low in both stations ranging from 0 to $15 \mathrm{~m} / \mathrm{s}$, with an average close to $4 \mathrm{~m} / \mathrm{s}$. Southern and western wind directions were predominant in both stations. Usually, southerly and westerly winds had to flow over the dense part of the city before reaching the reference station, which was not the case for the Bankstown station. The above, in combination with the significantly higher anthropogenic heat generated around the reference station, resulted in a slight overheating of the reference zone and a moderate negative UHI intensity.
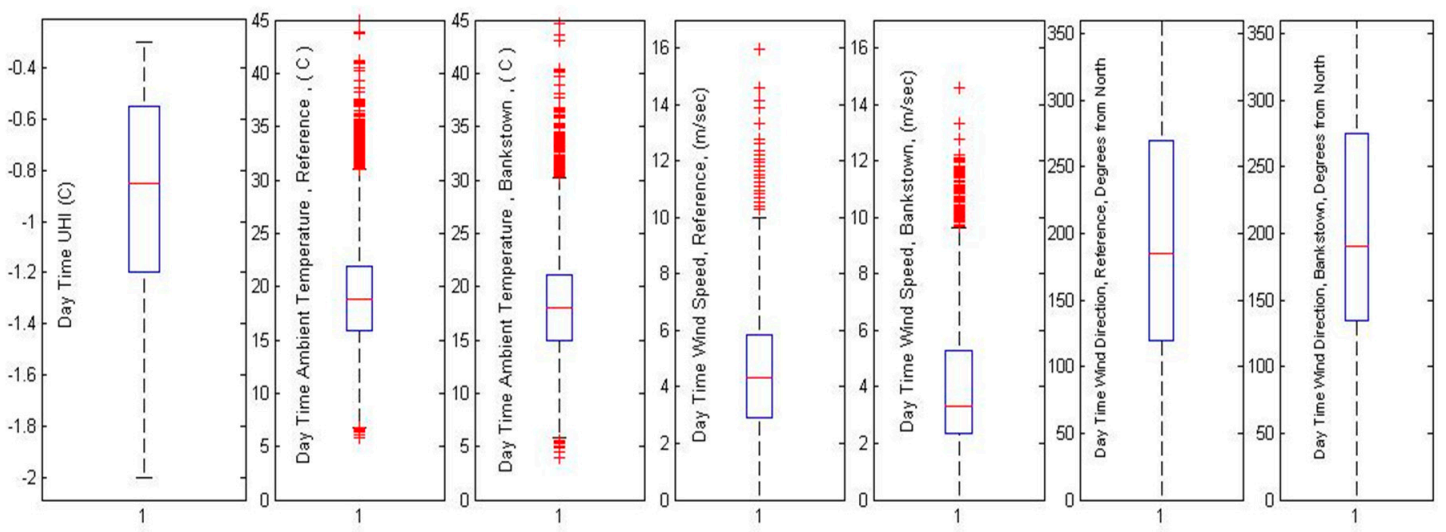

Figure 15. Levels of the daytime ambient temperature, wind speed and wind direction in the reference and the Bankstown stations in the fourth cluster. 
Fifth Cluster: Medium and High Negative UHI intensity. The fifth cluster includes data from all cases where the UHI intensity was negative and between $-2.0 \mathrm{~K}$ and $-6.2 \mathrm{~K}$. The corresponding data of the ambient temperature, wind speed and wind direction for both stations are given in Figure 16 . The ambient temperature in the reference station varied between $5.4{ }^{\circ} \mathrm{C}$ and $36.9^{\circ} \mathrm{C}$ with an average value around $16.5^{\circ} \mathrm{C}$, while at the Bankstown station temperature fluctuated between $1.9^{\circ} \mathrm{C}$ and $31.9{ }^{\circ} \mathrm{C}$ with an average close to $13.4{ }^{\circ} \mathrm{C}$. The cluster is characterized by considerably low wind speeds. The average wind speed at the reference and Bankstown stations are $3 \mathrm{~m} / \mathrm{s}$ and $1.6 \mathrm{~m} / \mathrm{s}$ respectively. Thus, the convective and advective phenomena, like sea breeze, were not important and the temperature difference was mainly due to the magnitude of the sensible and anthropogenic heat generated in each place.

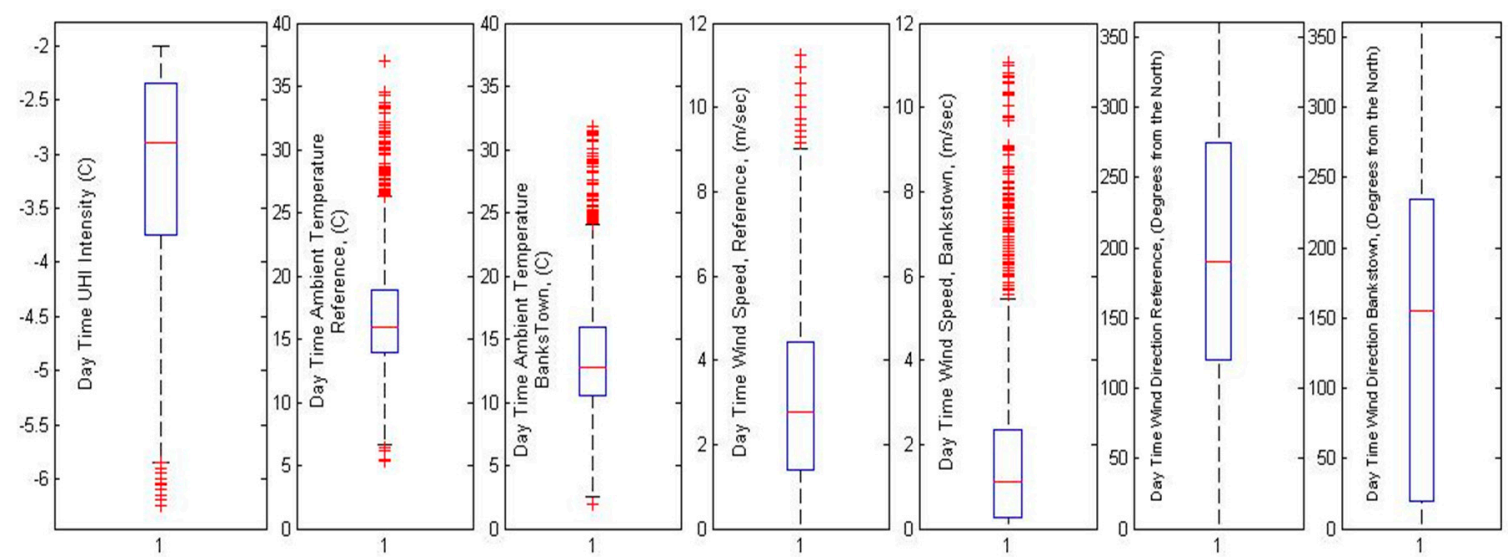

Figure 16. Levels of the daytime ambient temperature, wind speed and wind direction in the reference and the Bankstown stations in the fifth cluster.

Similar phenomena are also occurring and similar explanations are valid for the other two stations located in Western Sydney (Canterbury and Olympic Village). At both stations, an important increase in the UHI intensity is observed for increasing ambient temperatures (Figure 17) because of the important advective and convective phenomena associated with the particular synoptic conditions.

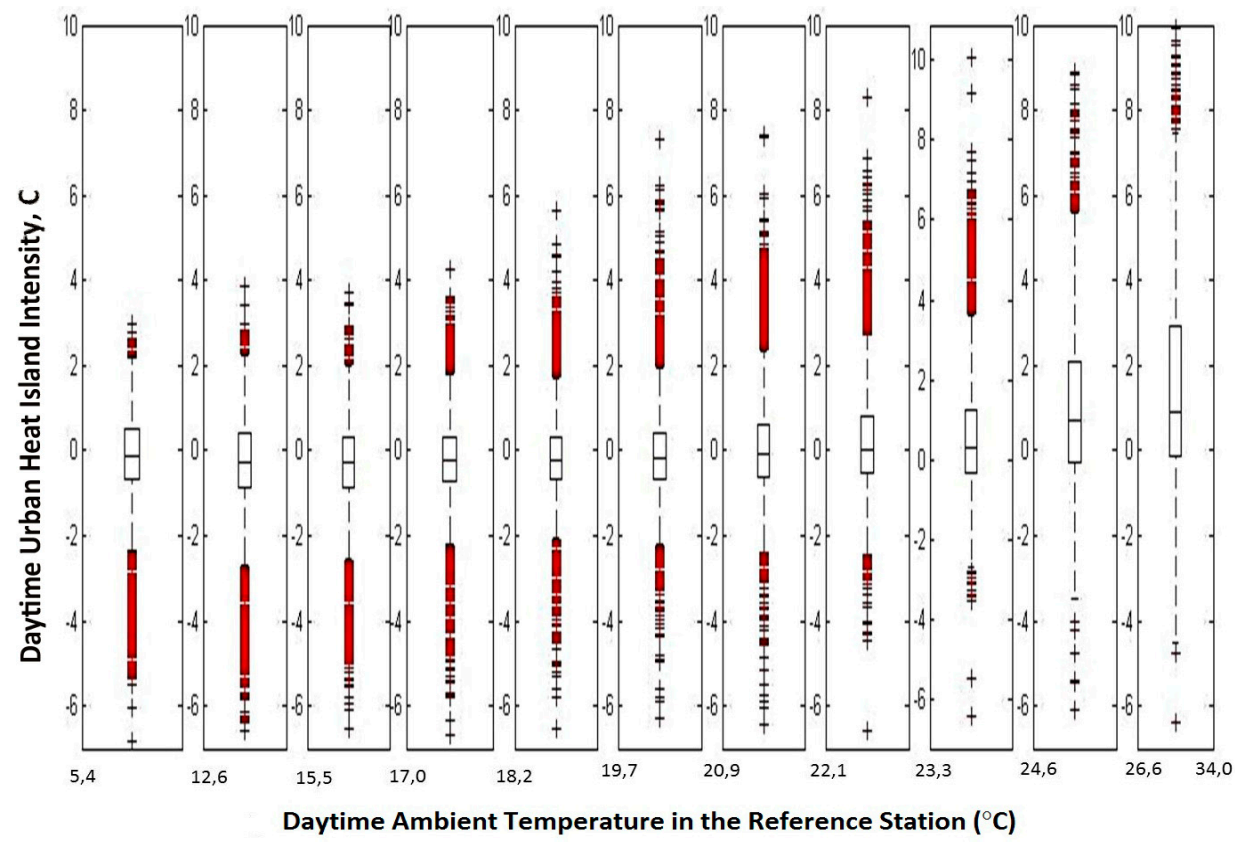

Figure 17. Levels of UHI intensity for different ambient temperatures at the Olympic Village. 
As concerns the station of Terrey Hills, the UHI is positive for $13.7 \%$ of the time, while for the rest of the period the ambient temperature is lower than in the reference station. Using clustering techniques, all data have been classified in three clusters. The first cluster is centred at $0.78 \mathrm{~K}$, and includes all climatic data corresponding to the positive values of the UHI intensity ranging between -0.3 and $6.4 \mathrm{~K}$. An analysis of the relevant climatic data in the cluster shows that high UHI values occur during the rare periods when the wind in Terrey Hills is from the inland area (western direction), while in the reference station the air is coming from the sea, Eastern direction. Under these synoptic conditions, warm air is advected in Terrey Hills, while, in parallel, low-temperature air is advected in the reference station, resulting in an important UHI intensity. The second cluster is centred around an UHI intensity close to $-1.3 \mathrm{~K}$ and includes almost $46 \%$ of the data. The UHI ranges between -0.3 and $-1.9 \mathrm{~K}$. The wind speed and direction are similar in both stations and the small negative UHI intensity is because of the additional anthropogenic heat in the reference station and the significant cooling rates caused by the evapotranspiration in Terrey Hills. Finally, the last cluster includes the climatic data corresponding to the high negative UHI intensities, up to $-4.0 \mathrm{~K}$. The maximum negative values occur when the wind in the reference station is flowing from the western direction, advecting warmer air to the station, while in Terrey Hills cooler air is flowing from northern and northeastern directions.

Finally, an analysis of the UHI intensity in the airport area has been performed using the same methodology as previously. Three clusters of climatic data have been defined. The first cluster includes all data corresponding to UHI intensities between $0.9 \mathrm{~K}$ and $5 \mathrm{~K}$; it is centred at $1.6 \mathrm{~K}$ and includes almost $28 \%$ of the data. High positive UHI values are observed only when the air flow in the airport is from the mainland, western direction, while at the reference station it is from the sea direction. The second cluster includes all data corresponding to low UHI intensities ranging between $-0.7 \mathrm{~K}$ and $0.9 \mathrm{~K}$. This cluster includes almost $56 \%$ of the data. The climatic conditions at both stations are quite similar and the observed temperature differences are due to the local heat effects. Finally, the third cluster includes all data corresponding to UHI intensities lower than $-0.7 \mathrm{~K}$ and is centred around $-1.4 \mathrm{~K}$. Quite important negative UHI intensities are observed only when the wind speed at the reference station is from the inland, western direction, while at the airport it is from the sea direction.

The whole analysis reveals that the development and magnitude of the UHI in the city are mainly governed by advection processes. The sea breeze is the main cooling mechanism in the city, while westerly winds from the country inland present the main heating mechanism during the warm period. During the summer, both mechanisms may co-exist, resulting in high temperature differences between the eastern and western parts of the city. Several other synoptic conditions and combinations may occur, resulting in smaller UHI intensities. A significant oasis phenomenon is also observed, mainly during the winter period, and during the days where the strength of the sea breeze is not significant and the heat generated in the city is not removed.

\section{Spatial Distribution of the Cooling Degree Days}

The severity of the climate and the resulting cooling energy demand can be described in terms of cooling degree days (CDDs). The cooling degree days (CDD) index was used in this analysis due to its correlation with UHI and energy consumption. Therefore, the annual cooling degree days were calculated with a base temperature of $23^{\circ} \mathrm{C}$, as a measure of cooling energy demand, for different locations in Greater Sydney based on the data from the six stations, enriched with additional data provided by the BizEE Degree Days online software tool [43]. This online tool uses temperature data from Weather Underground [44]. ArcGIS 10.3 (ArcGIS, Version 10.3, Esri, Redlands, CA, USA) software was used to obtain the exact location, analyse the spatial data, and illustrate the area under specified thermal conditions. The widely used Inverse Distance Weighted (IDW) interpolation technique was implemented to generate the spatial patterns of annual CDDs on the map. This method is based on the assumption that the nearest points surrounding a selected location have more influence on the prediction than those that are farther away. The IDW interpolation technique weights the points 
being evaluated based on the distance from the sampled location; the weight is a function of inverse distance [45].

For the calculation of CDDs, the period 2014-2016 was selected. It should be noted that detailed temperature readings, taken throughout each day for the six weather stations selected in this study, enable an intensive calculation process (the so-called Integration Method) to increase the accuracy of the resulting degree day data [43]. The calculated CDDs for the selected sites and years are shown in Figure 18.

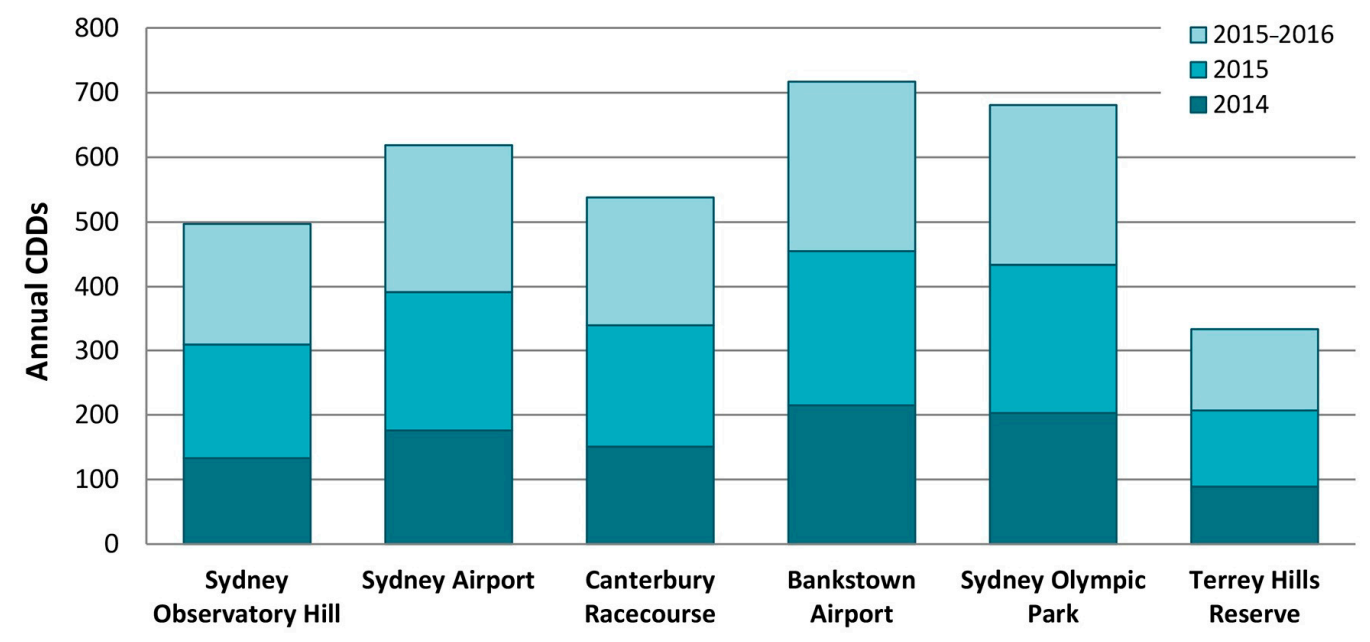

Figure 18. Calculated CDDs for the selected sites and years.

The result indicates that annual cooling degree-days ranged from 89 to 215 in 2014, being higher in Bankstown with $215^{\circ} \mathrm{C}$ day, followed by Sydney Olympic Park ( $203^{\circ} \mathrm{C}$ day). In contrast, the lowest CDDs is calculated for Terrey Hills Reserve with $89^{\circ} \mathrm{C}$ day located in the hilly forest district followed by Sydney Observatory Hill $\left(133{ }^{\circ} \mathrm{C}\right.$ day) located adjacent to Sydney Harbour in the coastal zone. In 2015, CDD values varied between 118 and 240, with a similar pattern observed in 2014. The trend of calculated CDDs in 2015-2016 is consistent with those in 2015 and 2014; however, CDDs have increased to $261^{\circ} \mathrm{C}$ day in Bankstown and $126^{\circ} \mathrm{C}$ day in Terrey Hills Reserve. The obtained range of CDDs and the spatial pattern appear to be influenced by topography and water proximity.

Figures 19-21 illustrate CDDs maps for Sydney Observatory Hill, Sydney Airport, Canterbury Racecourse, Bankstown Airport AWS, Sydney Olympic Park AWS, and Terrey Hills Reserve in 2014 and 2015, and 2015-2016 respectively. Figures 19-21 suggest that CDDs are clearly different from station to station, showing a great spatial variability. The areas located in the west and southwest, where Bankstown airport station is located, are characterized by higher annual CDDs compared to Observatory Hill in Sydney CBD and Terry Hills located in the northern suburbs. This pattern is consistent for all investigated years. However, CDDs have increased more drastically in recent years. The average annual CDD in 2016 is up to $47^{\circ} \mathrm{C}$ day higher than that in 2014 . This implies a growing cooling energy demand throughout Sydney.

Since CDD is an important index reflecting the climate and energy demand of buildings, the analysis is extended to calculate the cooling degree days of a larger region and compare CDD calculations for 24 different locations across the Sydney metropolitan area. Table 2 summarises the geographical location and CDDs of the extended weather stations based on data from November 2015 to October 2016. The spatial pattern of cooling degree days calculated for 24 sites is illustrated on the map (Figure 3). The results of such an investigation foster a better understanding of the climate and energy consumption of buildings in different climatic conditions. It should be noted that the Degree Day.net online tool is programmed to estimate CDD to account for missing temperature data [43]. 


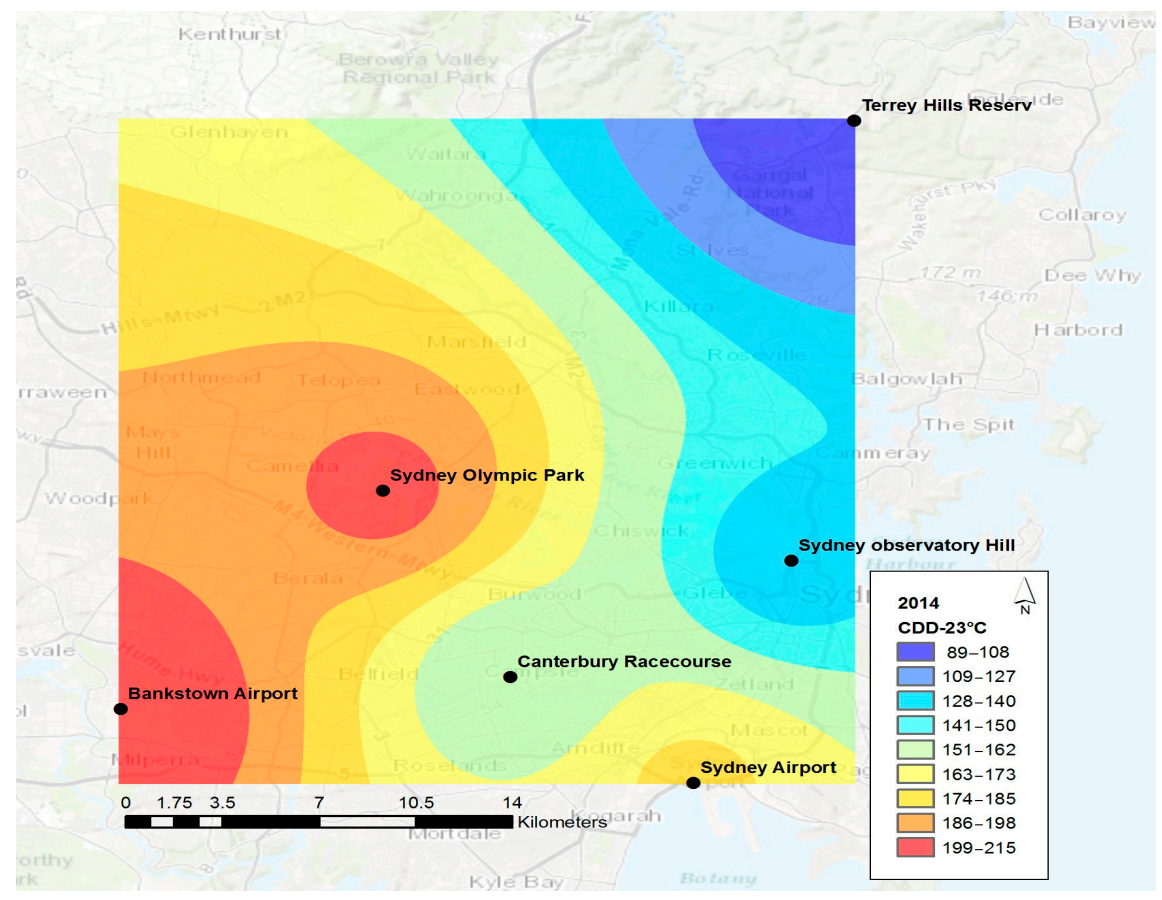

Figure 19. CDDs maps for Sydney Observatory Hill, Sydney Airport, Canterbury Racecourse, Bankstown Airport AWS, Sydney Olympic Park AWS, and Terrey Hills Reserve in 2014.

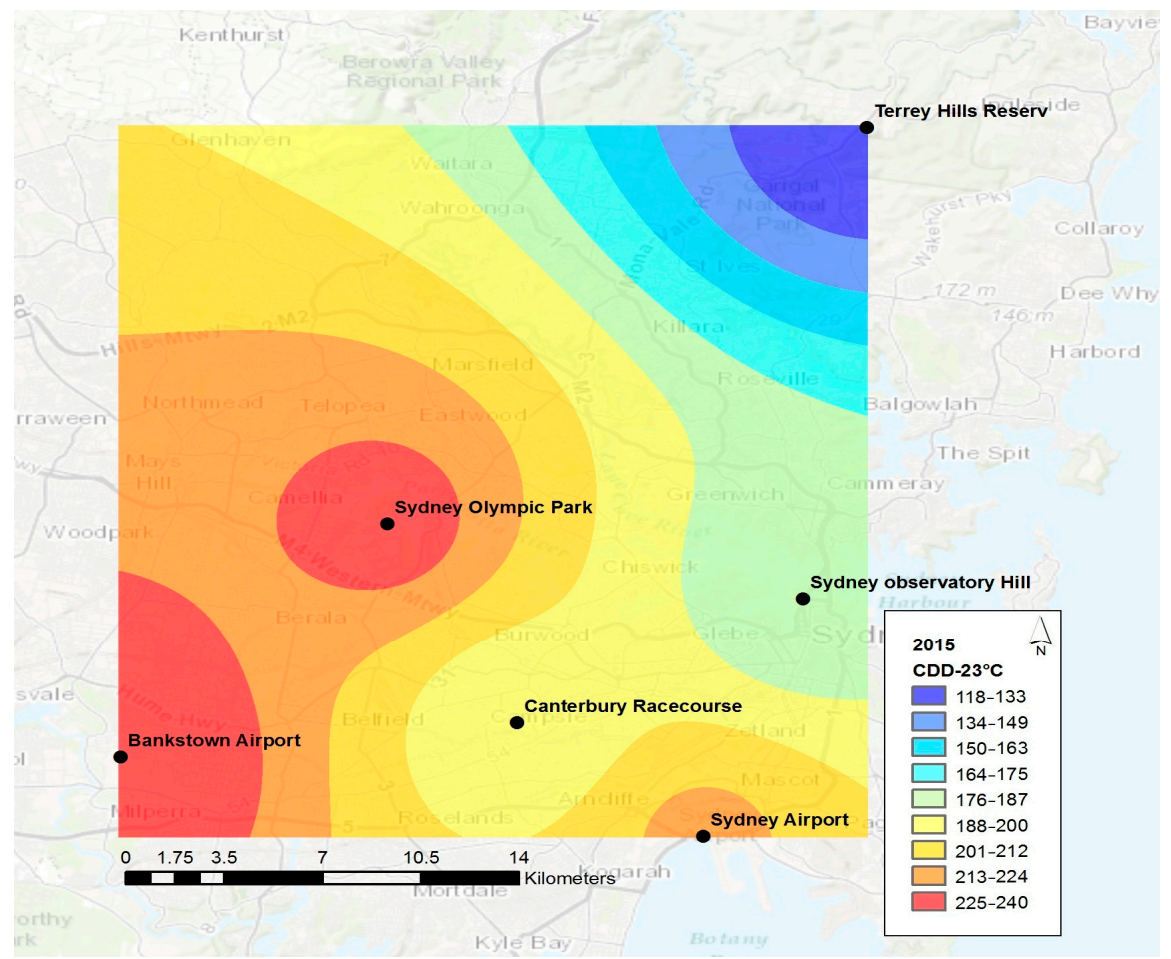

Figure 20. CDDs maps for Sydney Observatory Hill, Sydney Airport, Canterbury Racecourse, Bankstown Airport AWS, Sydney Olympic Park AWS, and Terrey Hills Reserve in 2015. 


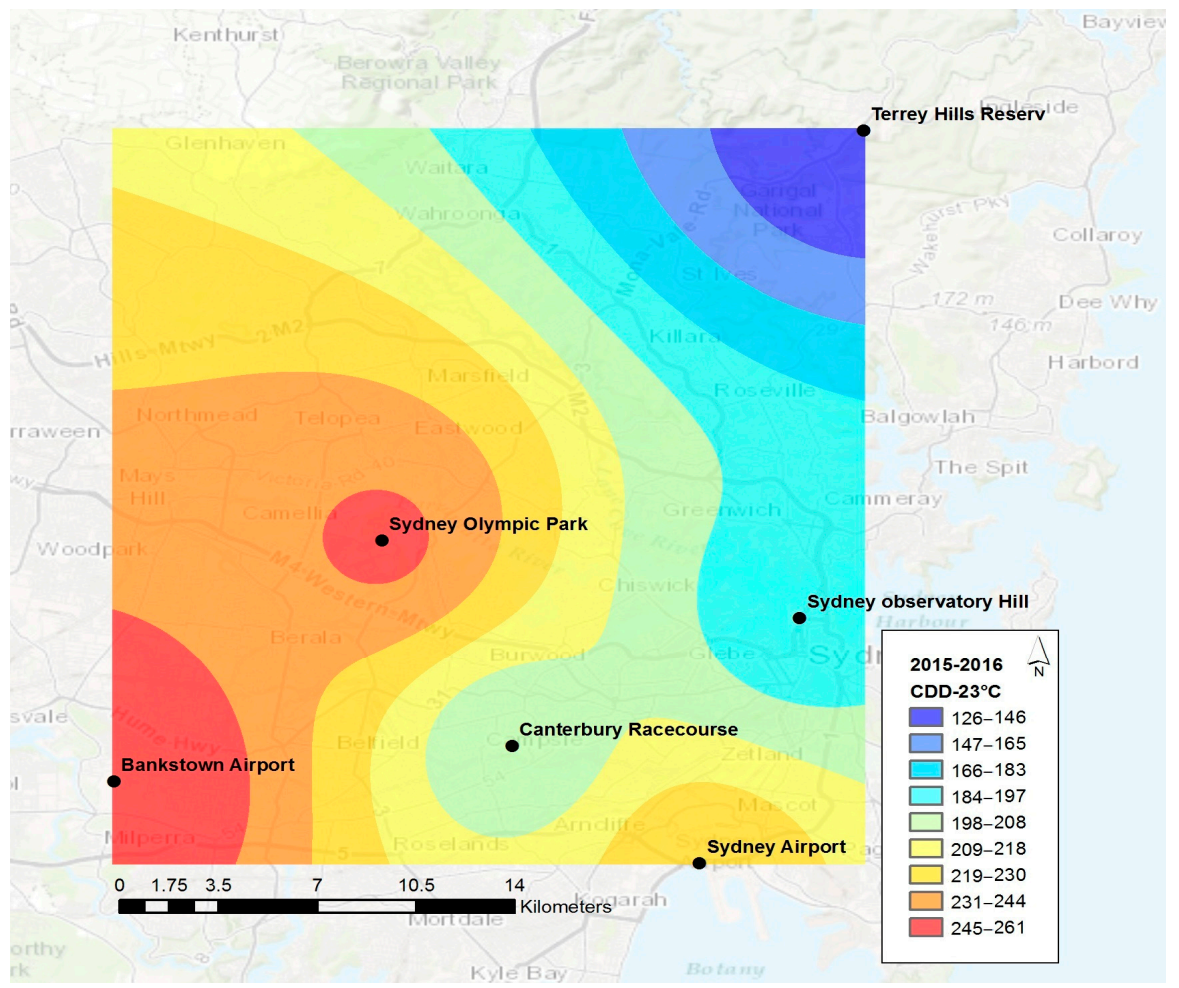

Figure 21. CDDs maps for Sydney Observatory Hill, Sydney Airport, Canterbury Racecourse, Bankstown Airport AWS, Sydney Olympic Park AWS, and Terrey Hills Reserve in November 2015October 2016.

Table 2. Description of the extended weather stations locations and CDD calculations based on data from 2015 to 2016.

\begin{tabular}{ccccc}
\hline Weather Station Locations & Longitude $\left({ }^{\circ}\right.$ E) & Latitude $\left({ }^{\circ}\right.$ S) & Region & CDD \\
\hline Sydney (Observatory Hill) & 151.21 & 33.86 & On the coast & 188 \\
Sydney Airport & 151.17 & 33.95 & On the coast & 227 \\
Canterbury Racecourse & 151.11 & 33.91 & Inland & 199 \\
Bankstown Airport AWS & 150.99 & 33.92 & Inland & 262 \\
Sydney Olympic Park AWS & 151.07 & 33.83 & Inland & 247 \\
Terrey Hills Reserve & 151.23 & 33.69 & Inland & 126 \\
Gymea Bay, South of Sydney & 151.08 & 34.05 & Inland & 241 \\
Horsley Park Equestrian Centre AWS & 150.86 & 33.85 & Inland & 239 \\
Richmond Aus-Afb & 150.78 & 33.60 & Inland & 294 \\
Penrith Lakes AWS & 150.68 & 33.72 & Inland & 310 \\
Blacktown, Blacktown & 150.89 & 33.77 & Inland & 443 \\
Campbell Town (mount Annan) & 150.77 & 34.06 & Inland & 232 \\
Ross Street, Glenbrook & 150.62 & 33.77 & Inland & 329 \\
Colyton, Colyton & 150.79 & 33.79 & Inland & 468 \\
Orchard Hills, Orchard Hills & 150.74 & 33.79 & Inland & 563 \\
Kissing Point rd, Turramurra & 151.13 & 33.74 & Inland & 232 \\
Koola Avenue, Davidson & 151.18 & 33.75 & Inland & 181 \\
Merrylands West & 150.97 & 33.84 & Inland & 425 \\
Wildthorn Avenue, Dural & 151.01 & 33.66 & Inland & 333 \\
Kentwell Street, Baulkham Hills & 150.99 & 33.76 & Inland & 282 \\
Cecil Hills, Cecil Hills & 150.85 & 33.89 & Inland & 422 \\
Leppington, Leppington & 150.82 & 33.95 & Inland & 343 \\
Lusty Street, Marrickville & 151.15 & 33.93 & Inland & 245 \\
Mascot, Mascot & 151.19 & 33.93 & Inland & 307 \\
\hline
\end{tabular}


As depicted in Table 2, the resulting cooling degree days for the extended weather station locations vary between $126^{\circ} \mathrm{C}$ day and $563{ }^{\circ} \mathrm{C}$ day in 2015-2016. Figure 22 shows that the spatial pattern and magnitude of CDD vary from location to location. A higher CDD was shown in the western Sydney suburbs, with significant increasing trends in inland areas located $30-40 \mathrm{~km}$ west of Sydney CBD. This finding shows that during the last 12 months (November 2015-October 2016), western suburban areas in Sydney have experienced a more severe climate with up to three times higher CDDs compared to Northern and central parts of Sydney. This suggests that significant cooling is required for some inland locations, especially those located in the west of Sydney. The observed spatial variation of the CDDs is likely explained by topographic variables, urban form, and proximity to ocean, lakes, forests, and grasslands.

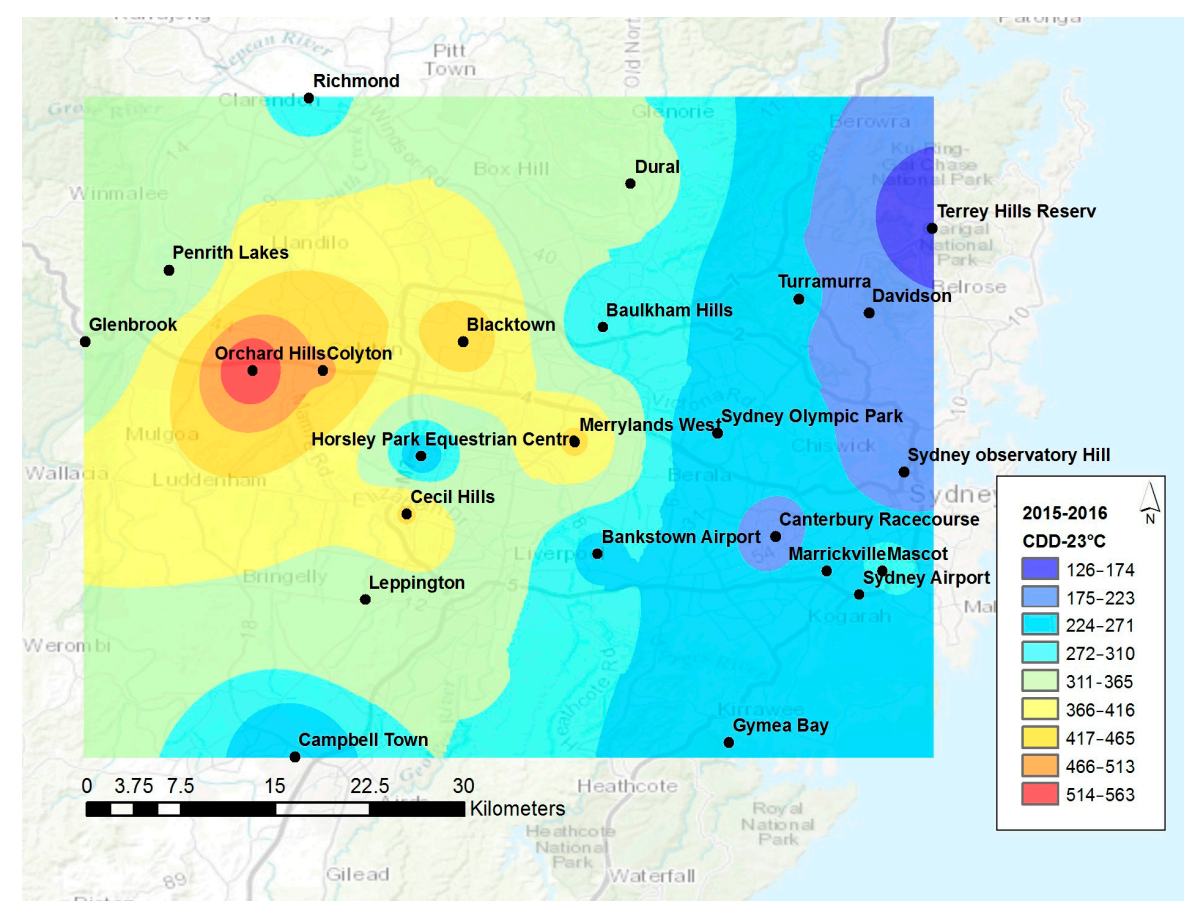

Figure 22. CDDs maps for the Sydney area considering data of 24 stations in November 2015October 2016.

\section{Conclusions}

Half-hourly climate data from six meteorological stations located in the greater Sydney area were used to analyse the magnitude and the characteristics of the UHI in the city. The whole analysis was performed for the period 2005-2010. It was found that important temperature differences exist between the eastern and western parts of the city. Both a strong UHI phenomenon and oasis phenomenon were observed. The average maximum magnitude of the phenomena reached up to $6 \mathrm{~K}$. The patterns of the ambient temperature distribution in the city were found to depend highly on the synoptic climatic conditions and the strength of the advection flows. High intensities of the UHI phenomenon were associated with the existence of a sea breeze in the eastern parts of the city, decreasing the temperature of the coastal zone, combined with westerly winds from the inland that heat up the western zones of the city. High intensities of the oasis phenomenon were associated with low wind speeds and a very weak development of the sea breeze in the coastal area. The important release of anthropogenic heat in the central and eastern parts of the city, combined with the reduced heat absorption in the western suburbs, intensified the magnitude of the oasis phenomenon. High UHI intensities were mainly observed during the warm summer period while the oasis phenomenon was stronger during the winter and the intermediate seasons. 
Using data on the Cooling Degree Days calculated from 23 stations located in the greater Sydney area for the period 2014-2015, it was found that the development of the UHI in Western Sydney may have a very significant impact on the cooling energy consumption of buildings and also on indoor and outdoor comfort conditions. It is characteristic that the CDD in Western Sydney is almost three times higher than in the central and northern parts of the city.

The whole analysis revealed the importance of local climate change and the UHI in coastal cities. Coastal urban zones that benefit from a sea breeze are more climate-resilient and are characterised by lower ambient temperatures than inland urban zones located quite far from the coast. The possible existence of an additional heating mechanism, like the advection of warm air from nearby spaces, may intensify the strength of the problem. Urban planning, considering the extension of coastal cities inland, should take into account the possible adverse climatic conditions and employ natural mitigation techniques able to dissipate the excess urban heat. The results of this study suggest that urban areas can significantly benefit from urban design and planning initiatives for heat reduction, e.g., by implementing bioclimatic urban design measures including increased vegetation and greenery, prevalence of shade, and reflective materials for roofs and pavement. Detailed investigation of these strategies is proposed for a subsequent paper. The use of advanced mitigation technologies is of importance in the reduction of adverse UHI-related health effects and the energy consumption of buildings.

Acknowledgments: The research has been financed and performed under the SJTU-UNSW Collaborative Research Fund-Seed Grant RG152786.

Author Contributions: Mattheos Santamouris, Xiaoqiang Zhai, and Ruzhu Wang conceived and designed the experiment; Mattheos Santamouris, Shamila Haddad and Francesco Fiorito performed the experiments; Mattheos Santamouris and Shamila Haddad analyzed the data; Mattheos Santamouris and Shamila Haddad wrote the paper; Francesco Fiorito, Paul Osmond, Lan Ding, and Deo Prasad contributed material and contributed to the writing and editing of this paper.

Conflicts of Interest: The authors declare no conflict of interest.

\section{References}

1. Santamouris, M. Analyzing the heat island magnitude and characteristics in one hundred Asian and Australian cities and regions. Sci. Total Environ. 2015, 512-513, 582-598. [CrossRef] [PubMed]

2. Santamouris, M. Innovating to zero the building sector in Europe: Minimising the energy consumption, eradication of the energy poverty and mitigating the local climate change. Sol. Energy 2016, 128, 61-94. [CrossRef]

3. Santamouris, M.; Kolokotsa, D. (Eds.) Urban Climate Mitigation Techniques; Routledge: London, UK, 2016.

4. Santamouris, M. Regulating the damaged thermostat of the Cities—Status, Impacts and Mitigation Strategies. Energy Build. 2015, 91, 43-56. [CrossRef]

5. Santamouris, M.; Cartalis, C.; Synnefa, A.; Kolokotsa, D. On The Impact of Urban Heat Island and Global Warming on the Power Demand and Electricity Consumption of Buildings-A Review. Energy Build. 2015, 98, 119-124. [CrossRef]

6. Santamouris, M. On The Energy Impact of Urban Heat Island and Global Warming on Buildings. Energy Build. 2014, 82, 100-113. [CrossRef]

7. Santamouris, M.; Papanikolaou, N.; Livada, I.; Koronakis, I.; Georgakis, C.; Argiriou, A.; Assimakopoulos, D.N. On the Impact of Urban Climate to the Energy Consumption of Buildings. Sol. Energy 2001, 70, 201-216. [CrossRef]

8. Hassid, S.; Santamouris, M.; Papanikolaou, N.; Linardi, A.; Klitsikas, N.; Georgakis, C.; Assimakopoulos, D.N. The Effect of the Athens Heat Island on Air Conditioning Load. J. Energy Build. 2000, 32, 131-141. [CrossRef]

9. Santamouris, M. Cooling of Buildings-Past, Present and Future. Energy Build. 2016, 128, 617-638. [CrossRef]

10. Pal, S.; Xueref-Remy, I.; Ammoura, L.; Chazette, P.; Gibert, F.; Royer, P.; Dieudonné, E.; Dupont, J.C.; Haeffelin, M.; Lac, C.; et al. Spatio-temporal variability of the atmospheric boundary layer depth over the Paris agglomeration: An assessment of the impact of the urban heat island intensity. Atmos. Environ. 2012, 63, 261-275. [CrossRef] 
11. Pantavou, K.; Theoharatos, G.; Mavrakis, A.; Santamouris, M. Evaluating Thermal Comfort Conditions and Health Responses during an extremely hot summer in Athens. Build. Environ. 2011, 46, 339-344. [CrossRef]

12. Sakka, A.; Santamouris, M.; Livada, I.; Nicol, F.; Wilson, M. On the thermal performance of low income housing during heat waves. Energy Build. 2012, 49, 69-77. [CrossRef]

13. Graham, D.A.; Vanos, J.K.; Kenny, N.A.; Brown, R.D. The relationship between neighbourhood tree canopy cover and heat-related ambulance calls during extreme heat events in Toronto, Canada. Urban For. Urban Green. 2016, 20, 180-186. [CrossRef]

14. Vanos, J.K.; Warland, J.S.; Gillespie, T.J.; Slater, G.A.; Brown, R.D.; Kenny, N.A. Human energy budget modeling in urban parks in Toronto and applications to emergency heat stress preparedness. J. Appl. Meteorol. Climatol. 2012, 51, 1639-1653. [CrossRef]

15. Baccini, M.; Biggeri, A.; Accetta, G.; Kosatsky, T.; Katsouyanni, K.; Analitis, A.; Anderson, H.R.; Bisanti, L.; D'Ippoliti, D.; Danova, J.; et al. Heat effects on mortality in 15 European cities. Epidemiology 2008, 19, 711-719. [CrossRef] [PubMed]

16. Von Glasow, R.; Jickells, T.D.; Alexander, B.; Carmichael, G.R.; Church, T.M.; Gallardo, L.; Hughes, C.; Kanakidou, M.; Liss, P.S.; Mee, L.; et al. Megacities and Large Urban Agglomerations in the Coastal Zone: Interactions Between Atmosphere, Land, and Marine Ecosystems. Ambio 2013, 13, 13-28. [CrossRef] [PubMed]

17. Ado, H.Y. Numerical study of the daytime urban effect and its interaction with the sea-breeze. J. Appl. Meteorol. 1992, 31, 1146-1164. [CrossRef]

18. Yoshikado, H. Interaction of the sea-breeze with urban heat islands of different sizes and locations. J. Meteorol. Soc. Jpn. 1994, 72, 139-143. [CrossRef]

19. Yoshikado, H.; Tsuchida, M. High levels of winter air pollution under the influence of the urban heat island along the shore of Tokyo Bay. J. Appl. Meteorol. 1996, 35, 1804-1814. [CrossRef]

20. Ohashi, Y.; Kida, H. Local circulations developed in the vicinity of both coastal and inland urban areas: A numerical study with a mesoscale atmospheric model. J. Appl. Meteorol. 2002, 41, 30-45. [CrossRef]

21. Khan, S.M.; Simpson, R.W. Effect of a heat island on the meteorology of complex urban airshed. Bound. Layer Meteorol. 2001, 100, 487-506. [CrossRef]

22. Gedzelman, S.D.; Austin, S.; Cermak, R.; Stefano, N.; Partridge, S.; Quesenberry, S.; Robinson, D.A. Mesoscale aspects of the urban heat island around New York City. Theor. Appl. Climatol. 2003, 75, $29-42$.

23. Freitas, E.; Rozoff, C.M.; Cotton, W.R.; Silva Dias, P.L. Interactions of an urban heat island and sea-breeze circulations during winter over the metropolitan area of São Paulo, Brazil. Bound. Layer Meteorol. 2007, 122, 43-65. [CrossRef]

24. Dandou, A.; Tombrou, M.; Soulakellis, M. The Influence of the City of Athens on the Evolution of the Sea-Breeze Front. Bound. Layer Meteorol. 2009, 131, 35-51. [CrossRef]

25. Abdullah, M.; Abar, O. Urban heat island of Jeddah. JKAU Meterol. Environ. Arid Agric. Sci. 1991, $2,73-82$.

26. Saaroni, H.; Ben Dor, E.; Bitan, A.; Potchter, O. Spatial distribution and microscale characteristics of the urban heat island in Tel Aviv, Israel. Landsc. Urban Plan. 2000, 48, 1-18. [CrossRef]

27. Devi, S.S. Urban heat islands and environmental impact. In Proceedings of the Sixth Symposium on the Urban Environment AMS Forum: Managing our Physical and Natural Resources: Successes and Challenges 2006, Atlanta, GA, USA, 27 January-3 February 2006.

28. Hua, L.J.; Ma, Z.G.; Guo, W.D. The impact of urbanization on air temperature across China. Theor. Appl. Climatol. 2008, 93, 179-194. [CrossRef]

29. Sakaida, K.; Egoshi, A.; Kuramochi, M. Effects of sea breezes on mitigating urban heat island phenomenon: Vertical observation results in the urban center of Sendai. J. Geogr. 2011, 120, 2382-2391. [CrossRef]

30. Sakaida, K. Urban Heat Island in Sendai, Japan, with Special Emphasis on Its Broader Significance. 2014. Available online: http:/ / caos-a.geophys.tohoku.ac.jp/sympo/program/oral_assets/o-24p.pdf (accessed on 10 November 2016).

31. Australian Bureau of Statistics. Australian Statistical Geography Standard (ASGS): Volume 4-Significant Urban Areas, Urban Centres and Localities, Section of State; Australian Bureau of Statistics: Canberra, Australia, 2012.

32. Australian Bureau of Statistics. Regional Population Growth, Australia, 2014-15; Australian Bureau of Statistics: Canberra, Australia, 2015.

33. Bureau of Meteorology. Climate Classification Maps. 2016. Available online: http://www.bom.gov.au/jsp/ ncc/climate_averages/climate-classifications/index.jsp (accessed on 10 November 2016). 
34. Kottek, M.; Grieser, J.; Beck, C.; Rudolf, B.; Rubel, F. World map of the Köppen-Geiger climate classification updated. Meteorol. Z. 2006, 15, 259-263. [CrossRef]

35. Bureau of Meteorology. Climate Statistics for Australian Locations. 2016. Available online: http://www. bom.gov.au/climate/data/index.shtml (accessed on 10 November 2016).

36. Bureau of Meteorology. Climate Data; Bureau of Meteorology: Melbourne, Australia, 2016.

37. Jacobs, B.; Mikhailovich, N.; Delaney, C. Benchmarking Australia's Urban Tree Canopy: An I-Tree Assessment, Prepared for Horticulture Australia Limited by the Institute for Sustainable Futures; University of Technology Sydney: Sydney, Australia, 2014.

38. Erell, E.; Williamson, T. Intra-urban differences in canopy layer air temperature at a mid-latitude city. Int. J. Climatol. 2007, 27, 1243-1255. [CrossRef]

39. Papanikolaou, L.I.; Santamouris, M.; Niachou, K. The influence of wind speed on heat island phenomenon in Athens, Greece. Int. J. Vent. 2008, 6, 337-348.

40. Eliasson, I. Intra-urban nocturnal temperature differences: A multivariate approach. Clim. Res. 1996, 7, 21-30. [CrossRef]

41. Kim, Y.; Baik, J.-J. Daily maximum urban heat island intensity in large cities of Korea. Theor. Appl. Climatol. 2004, 79, 151-164. [CrossRef]

42. Mohan, M.; Kikegawa, Y.; Gurjar, B.R.; Bhati, S.; Kandya, A.; Ogawa, K. Urban heat island assessment for a tropical urban Air shed in India. Atmos. Clim. Sci. 2012, 2, 127-138.

43. BizEE. Degree Days.net-Custom Degree Day Data. 2016. Available online: http://www.degreedays.net (accessed on 3 November 2016).

44. Weather Underground. Historical Weather. 2016. Available online: https://www.wunderground.com (accessed on 10 November 2016).

45. Philip, G.M.; Watson, D.F. A Precise Method for Determining Contoured Surfaces. Aust. Pet. Explor. Assoc. J. 1982, 22, 205-212.

(C) 2017 by the authors. Licensee MDPI, Basel, Switzerland. This article is an open access article distributed under the terms and conditions of the Creative Commons Attribution (CC BY) license (http:/ / creativecommons.org/licenses/by/4.0/). 